\title{
Topoisomerase poisoning by the flavonoid nevadensin triggers DNA damage and apoptosis in human colon carcinoma HT29 cells
}

\author{
Lena Müller $^{1}$. Larissa Rhonda Friederike Schütte ${ }^{1}$. David Bücksteeg ${ }^{1}$ Julian Alfke ${ }^{1}$ Thomas Uebel $^{1}$. \\ Melanie Esselen ${ }^{1}$ (D)
}

Received: 7 May 2021 / Accepted: 16 September 2021 / Published online: 12 October 2021

(c) The Author(s) 2021

\begin{abstract}
Nevadensin, an abundant polyphenol of basil, is reported to reduce alkenylbenzene DNA adduct formation. Furthermore, it has a wide spectrum of further pharmacological properties. The presented study focuses the impact of nevadensin on topoisomerases (TOPO) in vitro. Considering the DNA-intercalating properties of flavonoids, first, minor groove binding properties $\left(\mathrm{IC}_{50}=31.63 \mu \mathrm{M}\right)$, as well as DNA intercalation $\left(\mathrm{IC}_{50}=296.91 \mu \mathrm{M}\right)$ of nevadensin, was found. To determine potential in vitro effects on TOPO I and TOPO II $\alpha$, the relaxation and decatenation assay was performed in a concentration range of $1-500 \mu \mathrm{M}$ nevadensin. A partial inhibition was detected for TOPO I at concentrations $\geq 100 \mu \mathrm{M}$, whereas TOPO II $\alpha$ activity is only inhibited at concentrations $\geq 250 \mu \mathrm{M}$. To clarify the mode of action, the isolating in vivo complex of enzyme assay was carried out using human colon carcinoma HT29 cells. After $1 \mathrm{~h}$ of incubation, the amount of TOPO I linked to DNA was significantly increased by nevaden $\sin (500 \mu \mathrm{M})$, why nevadensin was characterized as TOPO I poison. However, no effects on TOPO II $\alpha$ were detected in the cellular test system. As a subsequent cellular response to TOPO I poisoning, a highly significant increase of DNA damage after $2 \mathrm{~h}$ and a decrease of cell viability after $48 \mathrm{~h}$ at the same concentration range were found. Furthermore, after $24 \mathrm{~h}$ of incubation a $\mathrm{G}_{2} / \mathrm{M}$ arrest was observed at concentrations $\geq 100 \mu \mathrm{M}$ by flow cytometry. The analysis of cell death revealed that nevadensin induces the intrinsic apoptotic pathway via activation of caspase- 9 and caspase-3. The results suggest that cell cycle disruption and apoptotic events play key roles in the cellular response to TOPO I poisoning caused by nevadensin in HT29 cells.
\end{abstract}

Keywords Plant polyphenol $\cdot$ Flavone $\cdot$ Topoisomerase I $\cdot$ Caspase activity $\cdot$ Cell cycle arrest

$\begin{array}{ll}\text { Abbreviations } \\ \text { BCA } & \text { Bicinchoninic acid } \\ \text { BSA } & \text { Bovine serum albumin } \\ \text { CPT } & \text { Camptothecin } \\ \text { DMSO } & \text { Dimethyl sulfoxide } \\ \text { ETP } & \text { Etoposide } \\ \text { FCS } & \text { Fetal calf serum } \\ \text { FOX } & \text { Ferrous ion oxidation xylenol orange } \\ \text { HRP } & \text { Horseradish peroxidase } \\ \text { ICE } & \text { Isolating in vivo complex of enzyme } \\ \text { kDNA } & \text { Kinetoplast DNA } \\ \text { LDH } & \text { Lactate dehydrogenase } \\ \text { NADH } & \text { Nicotinamide adenine dinucleotide } \\ \text { NC } & \text { Negative control }\end{array}$

Melanie Esselen

esselen@uni-muenster.de

1 Institute of Food Chemistry, University of Münster, Corrensstraße 45, 48149 Münster, Germany

$\begin{array}{ll}\text { PBS } & \text { Phosphate-buffered saline } \\ \text { PC } & \text { Positive control } \\ \text { ROS } & \text { Reactive oxygen species } \\ \text { STP } & \text { Staurosporine } \\ \text { TAE } & \text { Tris-acetate-EDTA } \\ \text { TARDIS } & \text { Trapped in agarose DNA immunostaining } \\ \text { TOPO } & \text { Topoisomerase } \\ \text { TOPO I } & \text { Topoisomerase I } \\ \text { TOPOII } & \text { Topoisomerase II }\end{array}$

\section{Introduction}

Flavonoids are widely distributed throughout the plant kingdom and exhibit a high structural diversity. Daily dietary intake of mixed flavonoids is determined in the human population and ranges from 167 to $564 \mathrm{mg}$ per day, respectively (Wisnuwardani et al. 2019). Furthermore, this substance class is most commonly found in commercially 
available high-dose supplements with a daily recommended dose up to $2 \mathrm{~g}$ per day (Espín et al. 2007). For example, human plasma concentrations about $52 \mathrm{nM}$ of the abundant flavonol quercetin has been reported after normal dietary intake (Erlund et al. 2002). Flavonoid-associated health benefits comprise, for example, anti-inflammatory and anti-oxidative activities as well as protection against cardiovascular diseases (Ross and Kasum 200). Nevadensin (Fig. 1a), 5,7-dihydroxy-6,8,4'-trimethoxyflavone (CAS No.: 10176-66-6) belongs to the class of secondary plant metabolites. It is mainly found in Ocimum basicilum L. and Ocimum americanum $\mathrm{L}$. as well as in many other plants, such as Helianthus pumilus N., Lysionotus pauciflorus M. and Cheilanthes argentea F. (Berim and Gang 2016; Herz and Groote 1977). The concentrations of nevadensin are indicated between 0.6 and $14.6 \mathrm{mg} / \mathrm{kg}$ dry weight in basil (Grayer et al. 2001). Moreover, the quantity of nevadensin in basil-containing plant food supplements is reported to be in the range of 0.14-0.24 mg/g supplement (van den Berg et al. 2013).

To date, numerous studies highlight the bioactive properties of nevadensin, e.g. anti-inflammatory effects, antitumour and anti-carcinogenic activity, hypotensive activity, anti-tubercular, and anti-microbial activity (Brahmachari 2010). Furthermore, direct enzyme-modulating effects of flavonoids are already demonstrated in general as well as for nevadensin itself. Nevadensin is identified as a selective inhibitor of human carboxylesterase 1 by Wang and co-workers (2018). Moreover, nevadensin potently inhibits p40 protein tyrosine kinase activity with an $\mathrm{IC}_{50}$ value of $50 \mu \mathrm{g} / \mathrm{mL}$. Additionally, different in vitro and in vivo studies show that nevadensin reduces the amount of alkenylbenzenes-specific DNA adducts catalysed by sulfotransferases (Alhusainy et al. 2010). It should be noted that enzymemodulating properties of flavonoids are also controversially discussed in literature (Miron et al. 2017). Thereby, the enzyme class of topoisomerases (TOPO) is particularly of interest. TOPOs are nuclear phosphor proteins, ubiquitously occuring in eukaryotic as well as in prokaryotic cells. These enzymes are essential for nuclear processes that are strongly dependent on changes in DNA topology (Baranello et al. 2013). Changes in the topological arrangement are induced by relaxing torsional stress in supercoiled DNA sectors during initial steps of replication, transcription, and recombination (Baranello et al. 2013). TOPOs are classified into two main classes: type I and type II, which differ between their structure and their corresponding mode of action (Champoux 2001). Enzymes, which cleave single-strand breaks in DNA double helix are defined as topoisomerase I (TOPO I). The isoforms that cleave ATP-dependent double-strand breaks are known as topoisomerase II (TOPO II) (Deweese and Osheroff 2010). The catalytic cycles of both enzyme classes exhibit a fixed and characteristic order of successive steps and depends on contacting and detaching sequences between enzyme and double-strand DNA. The initial phase of the cycle is the generation of an incision in the DNA, also called nicking. Consequently, the DNA backbone breaks, and the DNA is attached to the enzyme. Subsequently, the DNA is rearranged in an unwound topology before closing the strand break. Finally, the catalytic cycle results in unwounded DNA and the release of the enzyme from the cleavage complex (Champoux 2001). This catalytic cycle is not an unregulated and autonomous pathway, so drugs can interact with the cleavage complex or specifically intercalate into the processed DNA at any level of the TOPO cycle.

Xenobiotics which influence TOPO activity are divided into two classes: the so-called TOPO poisons and the catalytic TOPO inhibitors. Fundamentally, poisons and inhibitors differ in their mode of action, whereby the poisons stabilise the enzyme/DNA complex, and the inhibitors interrupt the catalytic cycle of the enzyme before DNAbinding (Beretta et al. 2012, 2008). Both mechanisms result in an imbalance between enzyme/DNA complexes and free enzyme. Permanent DNA strand breaks above or below
Fig. 1 Chemical structure of nevadensin (a). Crucial structure criteria for flavonoids acting as traditional and redox-dependent topoisomerase poisons (b) modified according to Bandele et al. (2008). Redox-dependent poisoning is associated with DNA-binding affinity and oxidative transformation to quinones. In the case of traditional poisons, the hydroxy groups in positions C-5 and C-4', as well as the aromatic, planar $\mathrm{C}$ ring with a ketone group in position $\mathrm{C}-4$ are identified key elements a<smiles>COc1ccc(-c2cc(=O)c3c(O)c(OC)c(O)c(OC)c3o2)cc1</smiles>
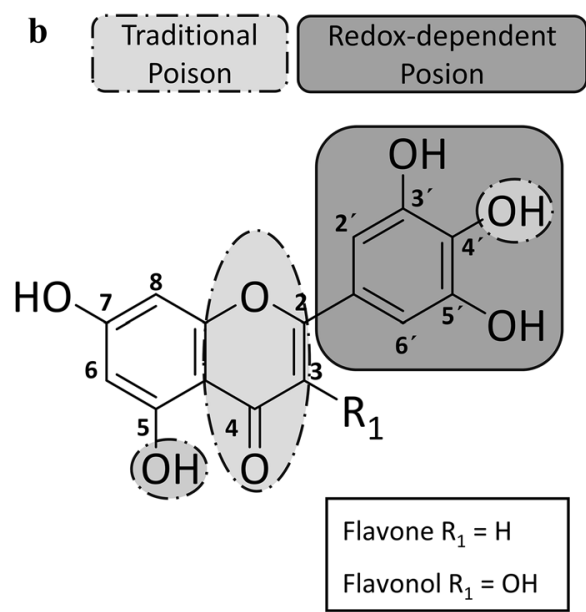
a critical level of enzyme/DNA complexes are induced, which cause the activation of stress-associated signalling pathways, e.g. cell cycle arrest or apoptosis induction by caspases activation. The effect intensity of TOPO inhibitors is roughly proportional to the cellular enzyme content. Accordingly, the DNA-damaging effect increase with higher TOPO concentrations. In fast proliferating malignant cells TOPO enzymes are highly expressed. Therefore, these cells particularly respond to TOPO-inhibiting effects (Beretta et al. 2012, 2008; Fry et al. 1991).

For this reason, TOPO poisons as well as catalytic inhibitors are attractive candidates for a clinical use as anti-cancer agents. Camptothecin (CPT) and its analogues topotecan, irinotecan, and namitecan are well-known TOPO I poisons. Further common cytostatic agents are TOPO II poisons such as the anthracycline doxorubicin or the podophyllotoxin etoposide (ETP) (Hevener et al. 2018). Besides these therapeutics, it is already known that a large number of foodborne compounds can strongly influence TOPO activity, which is exemplarily reviewed by Esselen and Barth (2014).

Different structural characteristics of flavonoids are discussed to be essential for the inhibition of the TOPO-mediated DNA relegation step (López-Lázaro et al. 2010; Mittra et al. 2000; Yamashita and Kawanishi 2000). In literature, they are classified as redox-dependent poisons (Fig. 1b; marked dark-grey) and traditional poisons (Fig. 1b, marked grey).

Due to the ubiquitous occurrence of flavonoids in food and furthermore in the expanded market of highly enriched and microencapsulated dietary supplements, an assessment of possible application restrictions of these compounds is of high relevance. So far, there are no studies on potential accumulative effects, but the consumption of natural TOPO poisons among the group of flavonoids during pregnancy is already associated with the clinical picture of infantile leukaemia (Spector et al. 2005; Strick et al. 2000).

This present study addressed the question whether the natural plant flavonoid nevadensin acts as a potential topoisomerase poison in vitro. Furthermore, the potential cellular responses including cell cycle distribution and apoptosis induction are investigated.

\section{Materials and methods}

\section{Chemicals}

HT29 cell line (DSMZ Cat\# ACC-299, RRID: CVCL_0320) was obtained from Leibnitz Institute DSMZ (Braunschweig, Germany). Nevadensin (CAS number: 10176-66-6, purity: > 99\%) was purchased from Biosynth Carbosynth (Berkshire, United Kingdom) and dimethyl sulfoxide (DMSO) from Carl Roth GmbH \& Co. KG (Karlsruhe,
Germany). All other chemicals were of the highest commercially available quality purchased from selected suppliers.

\section{Cell culture}

HT29 cells were cultured in Dulbecco's Modified Eagle's Medium (Gibco ${ }^{\circ}$, Thermo Fisher Scientific BV \& Co. KG, Braunschweig, Germany) supplemented with fetal calf serum (FCS; 10\%, Gibco®, Thermo Fisher Scientific BV \& Co. KG, Braunschweig, Germany) and penicillin/streptomycin (1\%, Gibco®, Thermo Fisher Scientific BV \& Co. $\mathrm{KG}$, Braunschweig, Germany) at $37^{\circ} \mathrm{C}, 5 \% \mathrm{CO}_{2}$ and relative humidity. The same conditions were used for all cell culture experiments. All cell culture experiments were carried out with an addition of $100 \mathrm{U} / \mathrm{mL}$ catalase (Sigma-Aldrich $\mathrm{GmbH}$, Seelze, Germany) to prevent the formation of hydrogen peroxide from nevadensin, widely reported for many flavonoids (Kern et al. 2007; Fritz et al. 2008; Long et al. 2000; Chai et al. 2003a, b). Furthermore, all cell culture experiments were carried out with nevadensin in a concentration range of $1-500 \mu \mathrm{M}$. DMSO $(1 \%)$ was used as negative control (NC) whereas camptothecin (CPT) served as positive control (PC) in all in vitro assays, excluding DNAintercalation assays and LDH assay. The CPT concentration was adjusted to the respective assay. Etoposide (ETP) served as positive control for decatenation assay and ICE-assay.

\section{DNA binding properties}

DNA-binding properties were measured according to the protocol of Morgen and co-workers (1979) modified by Habermeyer and co-workers (2005) in 96-well plates (Sarstedt, Nümbrecht, Germany). A decrease in fluorescence intensity resulted from the replacement of the intercalator ethidium bromide $(1 \mu \mathrm{M}$; Sigma-Aldrich $\mathrm{GmbH}$, Seelze, Germany) in double-stranded DNA (calf thymus DNA; Sigma-Aldrich GmbH, Seelze, Germany) or the minor-groove binder Hoechst 33258 (1 $\mu \mathrm{M}$; Sigma-Aldrich $\mathrm{GmbH}$, Seelze, Germany). Fluorescence was measured at $\lambda_{\mathrm{ex}}$ at $544 \mathrm{~nm}$ and $\lambda_{\mathrm{em}}$ at $590 \mathrm{~nm}$ or at $\lambda_{\mathrm{ex}}$ of $355 \mathrm{~nm}$ and $\lambda_{\mathrm{em}}$ of $460 \mathrm{~nm}$ with an Infinite M200 PRO microplate reader (Tecan Group Ltd., Männedorf, Switzerland), respectively.

\section{Relaxation assay}

Relaxation assay was carried out according to the protocol of Habermeyer and co-workers (2005). Effects of nevadensin on human TOPO I activity were investigated by the unwinding of supercoiled pUC18 DNA into its relaxed form. Plasmid DNA (250 ng pUC18) was incubated in a solution containing $1 \mu \mathrm{L}$ of TOPO I (nuclear extract of MCF-7 cells); $100 \mu \mathrm{M}$ Tris- $\mathrm{HCl} ; \mathrm{pH} 7.9 ; 1 \mathrm{M} \mathrm{KCl} ; 100 \mathrm{mM} \mathrm{MgCl}_{2} ; 5 \mathrm{mM}$ DTT; $5 \mathrm{mM}$ EDTA; and $0.3 \mathrm{mg} / \mathrm{mL}$ bovine serum albumin 
(BSA) for $30 \mathrm{~min}$ at $37{ }^{\circ} \mathrm{C}$. Reactions were stopped with $5 \%$ SDS solution ( $\mathrm{w} / \mathrm{v})$, and proteinase $\mathrm{K}$ solution $(10 \mathrm{mg} /$ $\mathrm{mL}$ ) was added. After that, incubation was repeated for $30 \mathrm{~min}$ at $37{ }^{\circ} \mathrm{C}$. Gel electrophoresis was carried out at $60 \mathrm{~V}$ for $3 \mathrm{~h}$ in an agarose gel 1\%, (w/v) with Tris-acetate/ EDTA (TAE) buffer (20 mL TAE stock solution: $242 \mathrm{~g}$ Tris, $100 \mathrm{~mL}$ EDTA (500 mM, pH 8), $57.1 \mathrm{~mL}$ acetic acid (99\%); ad $980 \mathrm{~mL} \mathrm{H}_{2} \mathrm{O}$ ). Finally, the gel was stained with ethidium bromide $(10 \mu \mathrm{g} / \mathrm{mL})$ for $20 \mathrm{~min}$ and detected with a ChemiDoc XRS system (Biorad, München, Germany).

\section{Decatenation assay}

Decatenation assay was performed to measure effects on the activity of TOPO II according to the protocol of Habermeyer and co-workers (2005). Catenated kinetoplast DNA (kDNA) (330 ng, TopoGEN, Ohio, US) was used as substrate for TOPO II. The assay was performed in a volume of $30 \mu \mathrm{L}$, containing $40 \mathrm{ng}$ of TOPO II (TopoGEN, Ohio, US); $50 \mathrm{mM}$ Tris, pH 7.9; $120 \mathrm{mM} \mathrm{KCl} ; 10 \mathrm{mM} \mathrm{MgCl}{ }_{2} ; 1 \mathrm{mM}$ ATP; $0.5 \mathrm{mM}$ DTT; $0.5 \mathrm{mM}$ EDTA; and $0.03 \mathrm{mg} / \mathrm{mL}$ BSA. Reaction mixtures were incubated at $37{ }^{\circ} \mathrm{C}$ for $60 \mathrm{~min}$. Reactions were stopped by adding proteinase $\mathrm{K}(1 \mathrm{mg} / \mathrm{mL})$ in $10 \%$ SDS-solution (w/v). Gel electrophoresis was carried out at $60 \mathrm{~V}$ for $3 \mathrm{~h}$ in an agarose gel 1\%, (w/v) with Tris-acetate/ EDTA (TAE) buffer (20 mL TAE stock solution: $242 \mathrm{~g}$ Tris, $100 \mathrm{~mL}$ EDTA (500 mM, pH 8), $57.1 \mathrm{~mL}$ acetic acid (99\%); ad $980 \mathrm{~mL} \mathrm{H}_{2} \mathrm{O}$ ). Finally, the gel was stained with ethidium bromide $(10 \mu \mathrm{g} / \mathrm{mL})$ for $20 \mathrm{~min}$ and detected with a ChemiDoc XRS system (Biorad, München, Germany).

\section{Isolating in vivo complex of enzyme (ICE) assay}

Isolating in vivo complex of enzyme (ICE) assay was performed with modifications as described previously by Esselen and co-workers (2009). For the ICE-assay, 3,000,000 HT29 cells were seeded in cell culture dishes and were cultivated for $72 \mathrm{~h}$. Cells were incubated with nevadensin, dimethyl sulfoxide (DMSO, 1\%) and CPT $(25 \mu \mathrm{M})$ or ETP $(25 \mu \mathrm{M})$ for $1 \mathrm{~h}$ under serum-free conditions. Medium was removed and cells were rinsed with phosphate-buffered saline (PBS; $25 \mathrm{~mL}$ stock solution: $4.2 \mathrm{~g} \mathrm{KH}_{2} \mathrm{PO}_{4}, 180 \mathrm{~g}$ $\mathrm{NaCl}, 8.18 \mathrm{~g} \mathrm{Na}_{2} \mathrm{HPO}_{4}$, pH 7.4 in $1 \mathrm{~L} \mathrm{H}_{2} \mathrm{O}$; ad $475 \mathrm{~mL} \mathrm{H}_{2} \mathrm{O}$ ). After that, cells were lysed with TE buffer (10 mM Tris, $\mathrm{pH}$ 8.0; 1 mM EDTA), containing 1\% $N$-laurylsarcosyl sodium salt (w/v). Cell lysate was layered onto a caesium chloride gradient with decreasing density from the bottom to the top. Polyallomer tubes (14 mL, SW40, Beckman Coulter GmbH, Krefeld, Germany) were centrifuged at 200,000 $g$ for $24 \mathrm{~h}$ at $20{ }^{\circ} \mathrm{C}$. Afterwards, gradient was fractionated $(450 \mu \mathrm{L} /$ fraction) from the top of the tube. DNA content of single fractions was determined with NanoDrop (PeqLab Biotechnologie $\mathrm{GmbH}$, Erlangen, Germany) spectrophotometer at
$260 \mathrm{~nm}$. All DNA-rich fractions were combined and blotted onto a nitrocellulose membrane using a slot blotting apparatus (Minifold II, Whatman/Schleicher \& Schuell, Dassel, Germany). Membrane was blocked with TBST buffer (200 mM Tris, pH 7.5; $1.37 \mathrm{M} \mathrm{NaCl} ; 1 \%$ Tween 20 (v/v)) containing 5\% low-fat powdered milk. Detection was carried out with a mouse monoclonal antibody, against TOPO I (100 kDa; dilution 1:100 (v/v)) (Santa Cruz Biotechnology Cat\# sc-271285), which is linked to horseradish peroxidase (HRP), or TOPO II $\alpha$ (170 kDa; dilution 1:100 (v/v)) (Santa Cruz Biotechnology Cat\# sc-165986). TOPO II $\alpha$ samples were incubated with secondary antibody m-IgGK BP-HRP in a dilution of 1:1000 (v/v) (Santa Cruz Biotechnology Cat\# sc-516102). Chemiluminescent signals were measured with the ChemiDoc XRS system (Biorad, München, Germany). ImageLab 5.0 (Biorad, München, Germany) was used for the analysis of the blots. Total DNA content of the fractions was related to the arbitrary light unit and plotted as test over control (T/C ([\%])

\section{Single-cell gel electrophoresis (comet assay)}

Comet assay was performed following the protocol of Gedik and co-workers (1998). Therefore, 500,000 HT29 cells were seeded in cell culture dishes and were cultivated for $72 \mathrm{~h}$. After that, cells were incubated with nevadensin, $\mathrm{NC}$ and PC $(100 \mu \mathrm{M})$ for $2 \mathrm{~h}$. After that, incubation medium was removed, and cells were rinsed with PBS. After removal of cells with trypsin, cell viability was determined with trypan blue. Cell viability of the samples should be $>80 \%$. A duplicate of each sample, which includes 45,000 cells, was centrifuged for $10 \mathrm{~min}$ at $440 \mathrm{~g}$ and $4{ }^{\circ} \mathrm{C}$. Cell pellets were resuspended in low melting agarose and transferred to normal melting agarose-coated microscope slides. After drying, coverslips were removed, and samples were lysed (89 ml lysis stock solution: $2.5 \mathrm{M}$ sodium chloride, $100 \mathrm{mM}$ $\mathrm{Na}_{2}$ EDTA, $10 \mathrm{mM}$ Tris, $1 \%$ (w/v) $N$-laurylsarcosyl sodium salt, pH 10; $1 \mathrm{ml}$ Triton X-100, $10 \mathrm{ml}$ DMSO) overnight at $4{ }^{\circ} \mathrm{C}$. For electrophoresis, DNA was equilibrated for $20 \mathrm{~min}$ in alkaline electrophoretic buffer at $4{ }^{\circ} \mathrm{C}$. After equilibration, electrophoresis was performed at $25 \mathrm{~V}$, with a constant current of $300 \mathrm{~mA}$, for $20 \mathrm{~min}$. Microscopy slides were washed three times with neutralisation buffer for $5 \mathrm{~min}$ at $4{ }^{\circ} \mathrm{C}$. DNA was stained with ethidium bromide $(0.01 \mathrm{mg} / \mathrm{mL})$, and DNA strand breaks were detected with a fluorescence microscope (Carl Zeiss Microscopy GmbH, Göttingen, Germany). For this purpose, $2 \times 50$ cells per slide and concentration were analysed with the Comet Assay IV System software (Perceptive Instruments, Suffolk, UK). Tail intensity was expressed as DNA signals in the comet head compared to the signals in the comet tail. Slides were encoded to provide an objective analysis. Intensities of the tail were expressed as T/C ([\%]). 


\section{Resazurin reduction assay}

Cytotoxicity was investigated with the resazurin reduction assay, which was performed according to protocol of O'Brien and co-workers (2000). For experimental procedure 35,000 or 17,500 HT29 cells, respectively, were grown in 48-well microtiter plates for $48 \mathrm{~h}$. Subsequently, cells were incubated with nevadensin, $\mathrm{NC}$ and $\mathrm{PC}(200 \mu \mathrm{M})$ in cell culture medium for different time points ( $24 \mathrm{~h}$ and $48 \mathrm{~h}$ ). After incubation, culture medium was removed, and cells were washed with PBS. After that, cells were incubated with resazurin solution (resazurin stock solution: $1.44 \mathrm{~g} \mathrm{KH}_{2} \mathrm{PO}_{4}$, $9 \mathrm{~g} \mathrm{NaCl}, 59.5 \mathrm{mg} \mathrm{Na}_{2} \mathrm{HPO}_{4}$ in $1 \mathrm{~L}$ bidest. $\mathrm{H}_{2} \mathrm{O} ; 1: 10$ diluted in serum-free media) for $1 \mathrm{~h}$ at $37{ }^{\circ} \mathrm{C}$. Fluorescence was measured at $\lambda_{\mathrm{ex}}=544 \mathrm{~nm}$ and $\lambda_{\mathrm{em}}=590 \mathrm{~nm}$ with an Infinite M200 PRO microplate reader (Tecan Group Ltd., Männedorf, Switzerland). The relative fluorescence intensity is proportional to the viability and was presented as test over control (T/C [\%]).

\section{Cell cycle analysis}

500,000 HT29 cells were seeded in cell culture dishes and were cultivated for $72 \mathrm{~h}$ to analyse cell cycle distribution. Subsequently, cells were incubated with $100 \mathrm{nM}$ nocodazole for $24 \mathrm{~h}$ for synchronisation in $\mathrm{G}_{2} / \mathrm{M}$ phase. Cells were rinsed with PBS, and nevadensin, $\mathrm{NC}$ and $\mathrm{CPT}$ (PC, $50 \mu \mathrm{M}$ ) were incubated for $24 \mathrm{~h}$. After that, cells were washed with PBS and were removed from culture dishes with accutase ${ }^{\circledR}$ (activity $>500 \mathrm{U} / \mathrm{mL}$; Pan Biotech, Aidenbach, Germany). Samples were centrifuged for $5 \mathrm{~min}$ at $200 \mathrm{~g}$. Supernatants were removed, and cell pellets were resuspended with PBS containing 5\% FCS (v/v). After a further centrifugation step, cell pellets were fixed with ice-cold ethanol $(70 \%$, v/v). On the day of measurement, samples were centrifuged again, and ethanol was removed. After a washing step with PBS, cell pellets were resuspended in $495 \mu \mathrm{L}$ PBS and $5 \mu \mathrm{L}$ RNase solution $(1 \mathrm{mg} / \mathrm{mL}$ in PBS) was added to each sample. Cell suspensions were mixed with $5 \mu \mathrm{L}$ propidium iodide $(2.5 \mathrm{mg} / \mathrm{mL})$ and incubated for $15 \mathrm{~min}$ on ice. The measurement was performed on the FC500 flow cytometer (Beckman Coulter, Krefeld, Germany) with a flow rate of $30 \mu \mathrm{L} /$ min. Excitation was performed at $488 \mathrm{~nm}$ and emission was detected at $620 \mathrm{~nm}$. Initially, cell duplicates and aggregates were excluded from the distribution of the phases, so that only single cells were presented in the respective histograms. The phases $\mathrm{G}_{0} / \mathrm{G}_{1}, \mathrm{~S}$, and $\mathrm{G}_{2} / \mathrm{M}$ are adapted to the solvent control and adopted for further samples. The distribution of the phases was set to $100 \%$ and expressed as T/C ([\%]).

\section{Caspase $-3,-8$ and -9 activity assays}

Apoptosis induction was determined by induction of caspase-3, -8 and -9 activity using the protocols previously described by Krug and co-workers (2018). Therefore, 900,000 HT29 cells were seeded in cell culture dishes and were cultivated for $72 \mathrm{~h}$. Cells were incubated with nevadensin, NC and PC $(1 \mu \mathrm{M})$ for $24 \mathrm{~h}$. Cells were rinsed with PBS, and $120 \mu \mathrm{L}$ ice-cold lysis buffer (10 mM TRIS, $100 \mathrm{mM} \mathrm{NaCl}, 1 \mathrm{mM}$ EDTA, and $1 \%$ Triton-X-100 in water) was added to each sample. After 15 min of lysis, cells were scraped off and transferred to reaction tubes. Lysates were centrifuged for $10 \mathrm{~min}$ at $10,000 \mathrm{~g}$ and $4{ }^{\circ} \mathrm{C}$. $30 \mu \mathrm{L}$ of supernatants was directly mixed with reaction solution, which consists of two parts of reaction buffer (50 mM PIPES, $12.7 \mathrm{mM}$ EDTA, $8.1 \mathrm{mM}$ CHAPS ad $100 \mathrm{~mL}$ with water, $\mathrm{pH}$ 7.4), three parts water, half a part caspase-substrates (1 mM Ac-DEVD-AFC for caspase-3, $1 \mathrm{mM}$ Ac-IETD-AFC for caspase-8 and $1 \mathrm{mM}$ Ac-LEHDAFC, for caspase-9, respectively (Sigma-Aldrich $\mathrm{GmbH}$, Seelze, Germany) and 0.05 parts 1 M DTT solution using black 96-well microtiter plates. Mixtures were incubated for $1 \mathrm{~h}$ at $37{ }^{\circ} \mathrm{C}$ under dark conditions and measured at $\lambda_{\mathrm{ex}}=405 \mathrm{~nm}$ and $\lambda_{\mathrm{em}}=520 \mathrm{~nm}$ with an Infinite M200 PRO microplate reader (Tecan Group Ltd., Männedorf, Switzerland). Results were expressed as $\mu \mathrm{mol} \mathrm{AFC} / \mu \mathrm{g}$ protein.

A bicinchoninic acid (BCA) assay kit (Sigma-Aldrich $\mathrm{GmbH}$, Seelze, Germany) was performed to determine total protein concentrations using external standard calibration with BSA. $15 \mu \mathrm{L}$ of each cell lysate was mixed with $200 \mu \mathrm{L}$ BCA reagent (BCA solution with $4 \%$ copper sulfate, $50+1,(\mathrm{v} / \mathrm{v}))$, in a 96 -well microtiter plate. Plate was incubated $30 \mathrm{~min}$ at $37^{\circ} \mathrm{C}$ and absorbance was measured with an Infinite M200 PRO microplate reader (Tecan Group Ltd., Männedorf, Switzerland) at $560 \mathrm{~nm}$.

\section{Lactate dehydrogenase (LDH) leakage assay}

Lactate dehydrogenase (LDH) leakage assay was performed according to the protocol of Krug and co-workers (2018). Incubation and sample preparation were performed as described for caspase assays. Besides cell lysate, incubation medium was also needed for the measurement. $15 \mu \mathrm{L}$ of lysate and $40 \mu \mathrm{L}$ of incubation medium were mixed with $200 \mu \mathrm{L}$ buffer solution (100 mM HEPES, $10 \mathrm{mM}$ sodium pyruvate and $0.21 \mathrm{mM} \mathrm{NADH}$, at $\mathrm{pH} 7.0$ ) in a 96-well microtiter plate and were incubated for $30 \mathrm{~min}$ at $37^{\circ} \mathrm{C}$. Absorption was measured every $2 \mathrm{~min}$ at $355 \mathrm{~nm}$ in an Infinite M200 PRO microplate reader (Tecan Group Ltd., Männedorf, Switzerland). 


\section{Hoechst 33342-staining for nuclear apoptosis analysis}

500,000 HT29 cells were seeded out in quadriPERM® plates including SuperFrost PLUS ${ }^{\mathrm{TM}}$ adhesion slides and were cultivated for $24 \mathrm{~h}$. Afterwards, cells were incubated with nevadensin, PC (CPT; $0.5 \mu \mathrm{M})$ and NC for $24 \mathrm{~h}$. The culture medium was removed, slides were washed two-times with PBS $(1 \times)$ and fixed with ice-cold methanol for $2 \mathrm{~h}$ at $-20{ }^{\circ} \mathrm{C}$. After removing methanol, the slides were air dried for $30 \mathrm{~min}$ and stained with $1 \mu \mathrm{g} /$ $\mathrm{mL}$ Hoechst 33342 in staining buffer $(20 \mathrm{mM}$ Tris- $\mathrm{HCl}$, $\mathrm{pH} 7 ; 150 \mathrm{mM} \mathrm{NaCl}, \mathrm{pH} 7$ ) on a laboratory shaker for $1 \mathrm{~h}$. Staining solution was removed and slides were washed three-times with washing solution $\left(2 \mathrm{mM} \mathrm{Cu}_{2} \mathrm{SO}_{4}, 0.2 \mathrm{M}\right.$ $\mathrm{CaCl}_{2} ; 2 \mathrm{M} \mathrm{NaCl} ; 0.2 \%$ Tween-20; $50 \mathrm{mM}$ citric acid) for 5 min. Slides were directly washed two-times with PBS $(1 \times)$ as well as two-times with pure water. Cover glasses were fixed on slides by using mowiol®. Slides were dried overnight at room temperature and detected with fluorescence microscope (Carl Zeiss Microscopy $\mathrm{GmbH}$, Göttingen, Germany) with a DAPI filter at $\lambda_{\text {ex }} 350 \mathrm{~nm} /$ $\lambda_{\text {em }} 461 \mathrm{~nm}$. For this purpose, 1000 nuclei per slide were counted for each sample whereby slides were encoded. The results were expressed as percentage of apoptotic cells related to total cell count. Staining solution as well as washing solution following the method of Ligasová and Koberna (2019).

\section{Ferrous ion oxidation xylenol orange (FOX) assay}

FOX assay was performed in accordance with the protocol of Jiang and co-workers with slight modifications (Jiang et al. 1992). Nevadensin in a final concentration of $250 \mu \mathrm{M}$ was incubated in a 6 -well plate in serum-free culture medium. Two differnt experimental approches were incubated, with and without catalase addition $(100 \mathrm{U} / \mathrm{mL})$. Incubation was carried out under cell culture condition for $24 \mathrm{~h}$ as described in Sect. 2.2. At selected times (0.5, $1.0,2.0,24.0 \mathrm{~h}), 90 \mu \mathrm{L}$ of medium was taken and mixed with $10 \mu \mathrm{L} \mathrm{MeOH}$ in a reaction tube. Thereafter, $900 \mu \mathrm{L}$ of freshly prepared FOX reagent $\left(\left(\mathrm{NH}_{4}\right)_{2} \mathrm{FE}^{\mathrm{II}}\left(\mathrm{SO}_{4}\right)_{2}\right.$ $250 \mu \mathrm{M}, \mathrm{H}_{2} \mathrm{SO}_{4} 25 \mathrm{mM}$, xylenol orange tetrasodium salt $100 \mu \mathrm{M}$, and $\mathrm{D}-(-)$-sorbitol $100 \mathrm{mM}$ ) were added and homogenised on a laboratory shaker. After 30 minutes of incubation, an aliquot of $200 \mu \mathrm{L}$ was transferred into a 96-well plate. Absorption was measured at $550 \mathrm{~nm}$ in an Infinite M200 PRO microplate reader (Tecan Group Ltd., Männedorf, Switzerland). Hydrogen peroxide concentration was determined with an external calibration in a range between 0 and $60 \mu \mathrm{M} \mathrm{H}_{2} \mathrm{O}_{2}$.

\section{Statistics and graphical software}

Statistical evaluation was carried by using one-way ANOVA, followed by Tukey as post-hoc test. The presented data are the mean \pm standard deviation (SD) of at least more than three independent experiments. Data analysis and graphics were prepared by the OriginPro 9.7 Software (RRID:SCR_014212).

\section{Results and discussion}

\section{DNA intercalation and minor groove binding}

TOPO-poisoning effects of flavonoids are associated with their DNA-intercalating properties in literature (Snyder and Gillies 2002; Webb and Ebeler 2004; Bailly et al. 1999; Woynarowski et al. 1989). Therefore, at first the DNAinteracting properties of nevadensin were measured based on the replacement of the DNA intercalator ethidium bromide and the minor groove binder Hoechst 33258. Based on literature data for different flavonoids a relatively wide concentration range between 1 and $500 \mu \mathrm{M}$ was chosen (Webb and Ebeler 2004). Nevadensin was incubated with double-stranded DNA, Hoechst 33258 or ethidium bromide and fluorescence was measured. The procedures were controlled by using the PCs netropsin (for Hoechst 33258; $\mathrm{IC}_{50}: 0.31 \mu \mathrm{M} \pm 0.02 \mu \mathrm{M}$ ) and actinomycin $\mathrm{D}$ (for ethidium bromide displacement, $\mathrm{IC}_{50}: 1.93 \mu \mathrm{M} \pm 0.05 \mu \mathrm{M}$ ) (Supplementary Information Fig.S1). As demonstrated in Fig. 2a the intensity of fluorescence originating by Hoechst 33258 decreased with increasing concentrations of nevadensin (1-75 $\mu \mathrm{M})$. The $\mathrm{IC}_{50}$-value of nevadensin was determined at $31.63 \mu \mathrm{M} \pm 0.96 \mu \mathrm{M}$. The ethidium bromide displacement assay resulted in an $\mathrm{IC}_{50}$ of $296.91 \mu \mathrm{M} \pm 19.32 \mu \mathrm{M}$ (Fig. 2b). In sum, nevadensin was found to be more effective in Hoechst displacement assay and thus a higher affinity of nevadensin to the minor groove is consequently proposed.

In literature, the CPT derivative topotecan is also described to intercalate with DNA, whereas the underlying mode of action of CPT itself differs in the way of intercalation. CPT exhibits a poor or no binding to DNA or TOPO I alone, but it specifically trapped the DNA-TOPO I complex (Kerrigan and Pilch 2001). For the class of flavonoids, Webb and Ebeler (2004) suggest that DNA intercalation properties are not necessary, but sufficient for stabilisation of the cleavage complex. Their study provides structural alerts of flavones and flavanols, which are highly sufficient for DNA intercalators and TOPO I poisons. Nonetheless, some nonintercalating compounds are also capable to act as potent TOPO poisons (Webb and Ebeler 2004; Bailly et al. 1999). 


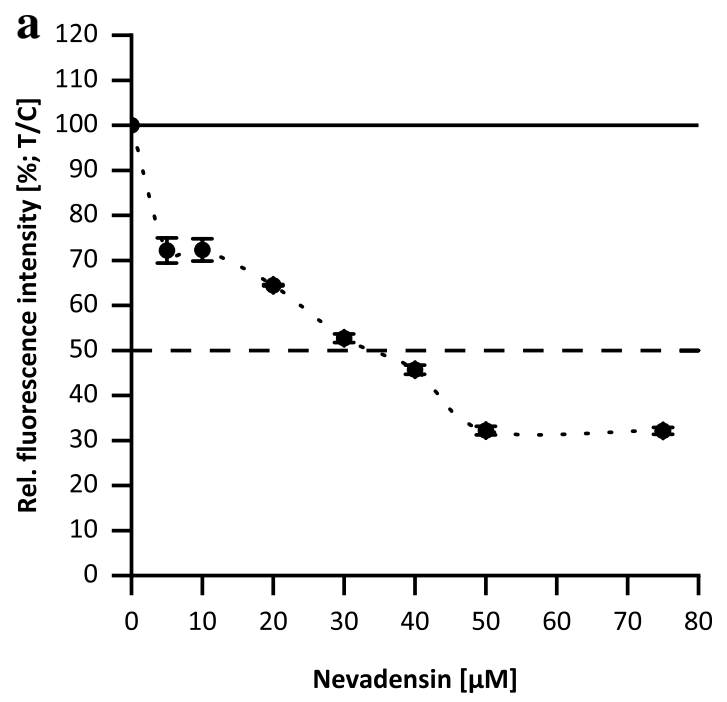

Fig. 2 DNA-binding affinity of nevadensin investigated by the displacement of the minor groove binder Hoechst 33,258 (a) and the DNA intercalator EtBr (b). DMSO (1\%) was used as negative control. The presented data are the mean \pm SD of three independent experi-

Taken the DNA-binding properties of nevadensin into account the question arises whether nevadensin has also an impact on human topoisomerase in vitro.

\section{Impact of nevadensin on topoisomerase enzymes}

The inhibitory potential of nevadensin on TOPO enzymes was investigated under cell-free conditions. First of all, the relaxation assay was performed to evaluate the impact on TOPO I. Active TOPO I enzymes catalyse the unwinding

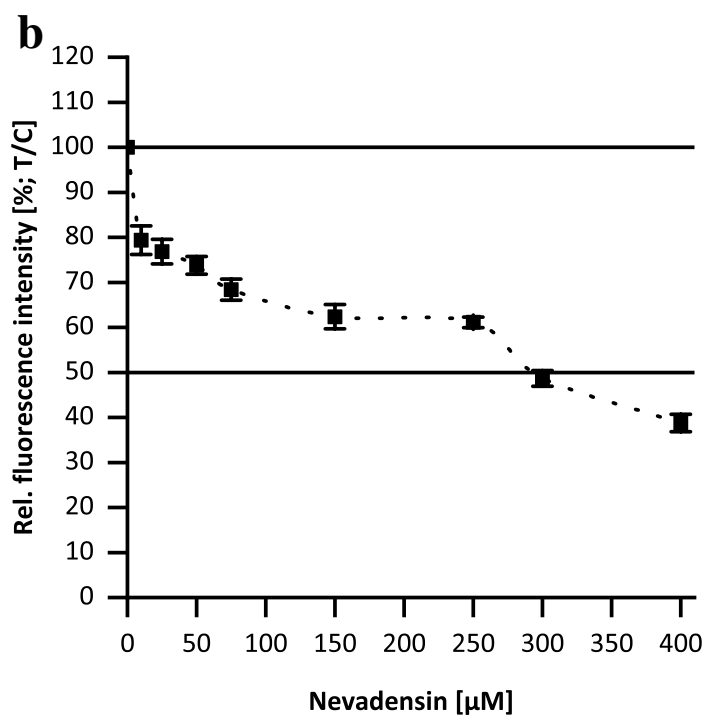

ments. The rel. fluorescence intensity was normalised to the $\mathrm{NC}$ and shown as test over control (T/C). The intersection point of the dashed line shows the half-maximum effect $\left(\mathrm{IC}_{50}\right)$

of supercoiled plasmid DNA (pUC18) and the relaxed DNA is separated by agarose gel electrophoresis. Results of the relaxation assay are presented in Fig. 3, including the supercoiled form of the used plasmid DNA (lane 1), active TOPO I (lane 2). NC (DMSO 3.33\%, (lane 3), CPT $(100 \mu \mathrm{M}$; lane 4$)$ and of the test compound nevadensin in the respective concentrations (lane 5-lane 10). Nevadensin at concentrations $>100 \mu \mathrm{M}$ led to a decreased formation of the relaxed DNA form in line with an increase of the nicked form (lanes 8, 9). At $500 \mu \mathrm{M}$ nevadensin (lane 10)

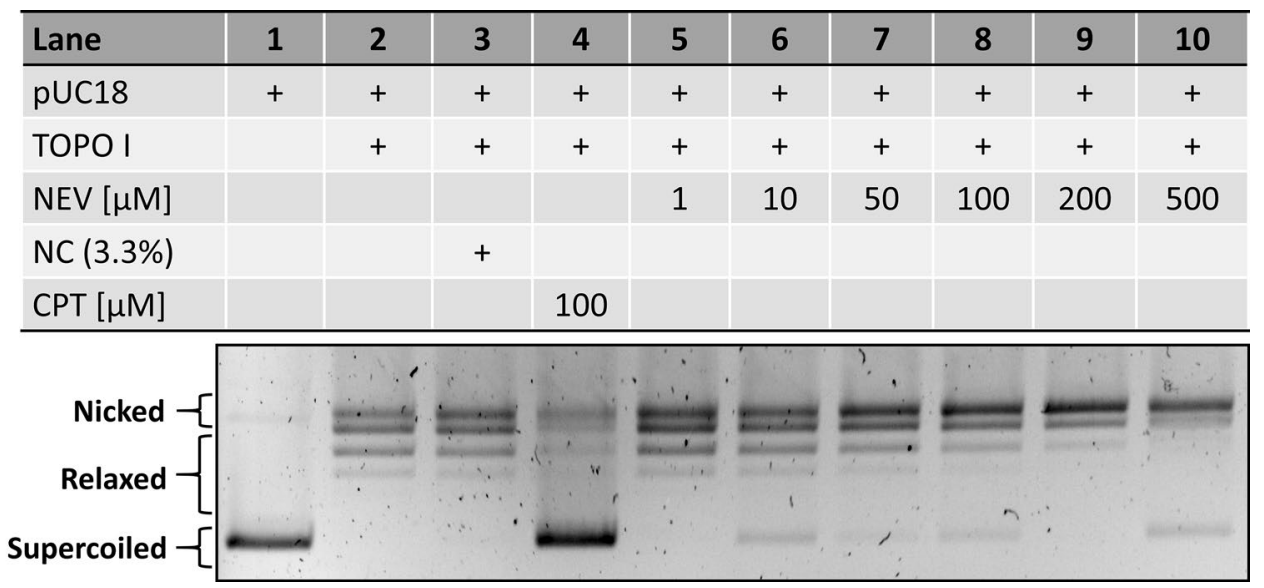

Fig. 3 Inhibition of TOPO I activity under cell-free conditions induced by nevadensin in the relaxation assay. The activity of the enzyme was monitored by the transformation of supercoiled pUC18 DNA in its relaxed form. One representative gel out of at least three independent experiments is shown. Lane 1: supercoiled pUC18 DNA, lane 2: active TOPO I, lane 3: negative control DMSO (NC; 3.3\%), lane 4: positive control camptothecin (CPT), increasing concentrations of nevadensin $(\mathrm{NEV}, 1-500 \mu \mathrm{M})$ (lane 5-lane 10) 
only intense signals for the supercoiled and the nicked DNA form were detected, suggesting a strong inhibitory effect.

Besides the effect on TOPO I the influence of nevadensin on TOPO II was also investigated with the decatenation assay. Results of the decatenation assay are presented in Fig. 4, including the catenated form of the kDNA (lane 1), active TOPO II $\alpha$ (lane 2). NC (DMSO 3.33\%, (lane 3), ETP $(100 \mu \mathrm{M}$; lane 4$)$ and of the test compound nevadensin in the respective concentrations (lane 5-lane 10). Nevadensin at concentrations $250 \mu \mathrm{M}$ led to a decreased formation of the decatenated DNA form in line with an increase of the catenated DNA (lanes 8, 9). At $500 \mu \mathrm{M}$ nevadensin (lane 10) the TOPO II $\alpha$ activity is nearly completely inhibited, compared to the ETP. Consequently, nevadensin is suggested to act as TOPO I and TOPO II $\alpha$ inhibitor, whereas the effect strength on TOPO II $\alpha$ is more prominent under cell-free conditions.

Based on the above-mentioned results, the mode of action of nevadensin on TOPO I and TOPO II $\alpha$ was characterised in more detail. Different modes of action of TOPO inhibition including catalytic inhibitors and TOPO poisons are described in literature. TOPO poisons stabilise the TOPO/ DNA complex, the so-called cleavage complex. To clarify if nevadensin acts as a catalytic inhibitor or poison, the cellular-based ICE-assay was performed. After separation of DNA-bound TOPO from free TOPO protein, the amount of TOPO linked to DNA was chemoluminometrically analysed. As clearly shown in Fig. 5, the amount of DNA-bound TOPO I significantly increases at a concentration of $500 \mu \mathrm{M}$ nevadensin. The lower concentrations also demonstrated a marginal increase but without but without significant relevance. However, no stabilising effects on TOPO II $\alpha / D N A$ complexes were detected for nevadensin (Supplementary Information Fig. S2).
Concerning these findings, nevadensin was identified as selective TOPO I poison. Slight differences in the effective strength of nevadensin against the isolated and the cellular enzyme was found. Partial inhibition of enzyme activity was achieved at concentrations higher $100 \mu \mathrm{M}$ in the cell-free assay. In contrast, significant TOPO I-poisoning effects were only detected at a concentration of $500 \mu \mathrm{M}$ in HT29 cells. In comparison to the positive control CPT, the poisoning effect of nevadensin is noticeably lower. Interestingly, a total inhibition of TOPO II $\alpha$ was also detected in the cell-free test system with isolated enzyme at $500 \mu \mathrm{M}$, whereas a poisoning effect was not verifiable in the cellular test system. Therefore, it is assumed that the concentration of $500 \mu \mathrm{M}$ was not sufficient to interact with cellular TOPO II $\alpha$.

TOPO-poisoning effects of secondary plant constituents has been described for a wide spectrum of flavonoids. Effective concentrations are reported to be at the lower up to the moderate micromolar range in vitro. For example, fisetin $\left(3,3^{\prime}, 4^{\prime}, 7\right.$-tetrahydroxyflavon) and quercetin $\left(3,3^{\prime}, 4^{\prime}, 5,7-\right.$ pentahydroxyflavon $)$ achieved the half-minimal inhibitory concentrations ( $\mathrm{IC}_{50}$ values) at approximately $71 \mu \mathrm{M}$ and $42 \mu \mathrm{M}$ in cell-free TOPO I assay (Constantinou et al. 1995). In the trapped in agarose DNA immunostaining (TARDIS) assay myricetin $\left(3,3^{\prime}, 4^{\prime}, 5,5^{\prime}, 7\right.$-hexahydroxyflavone) showed TOPO I-poisoning effects at concentrations of approximately $111 \mu \mathrm{M}$ (López-Lázaro et al. 2010). A few flavonoids, e.g., genistein (4',5,7-trihydroxyisoflavone) act as TOPO II poisons. Bandele and Osherhoff demonstrated that myricetin acts as TOPO II $\alpha$ poison in purified system but did not show any interaction with cellular TOPO II $\alpha$ in ICE-assay, in line to the mentioned results with nevadensin (Bandele and Osheroff 2007), whereas investigation with TARDIS assay identified myricetin as prominent TOPO II $\beta$

\begin{tabular}{l|c|c|c|c|c|c|c|c|c|c}
\hline Lane & $\mathbf{1}$ & $\mathbf{2}$ & $\mathbf{3}$ & $\mathbf{4}$ & $\mathbf{5}$ & $\mathbf{6}$ & $\mathbf{7}$ & $\mathbf{8}$ & $\mathbf{9}$ & $\mathbf{1 0}$ \\
\hline kDNA & + & + & + & + & + & + & + & + & + & + \\
TOPO $\| \alpha$ & & + & + & + & + & + & + & + & + & + \\
NEV $[\mu \mathrm{M}]$ & & & & & 1 & 10 & 50 & 100 & 250 & 500 \\
NC $(3.3 \%)$ & & & + & & & & & & & \\
ETP $[\mu \mathrm{M}]$ & & & & 100 & & & & & & $=$ \\
\hline Catenated-\{ & $=$
\end{tabular}

Fig. 4 Inhibition of TOPO II $\alpha$ activity under cell-free conditions induced by nevadensin in the decatenation assay. The activity of the enzyme was monitored by the transformation of kDNA into free mini circles. One representative gel out of at least three independ- ent experiments is shown. Lane 1: kDNA, lane 2: active TOPO II $\alpha$, lane 3: negative control DMSO (NC; 3.3\%), lane 4: positive control etoposide (ETP), increasing concentrations of nevadensin (NEV, 1-500 $\mathrm{MM}$ ) (lane 5-lane 10) 

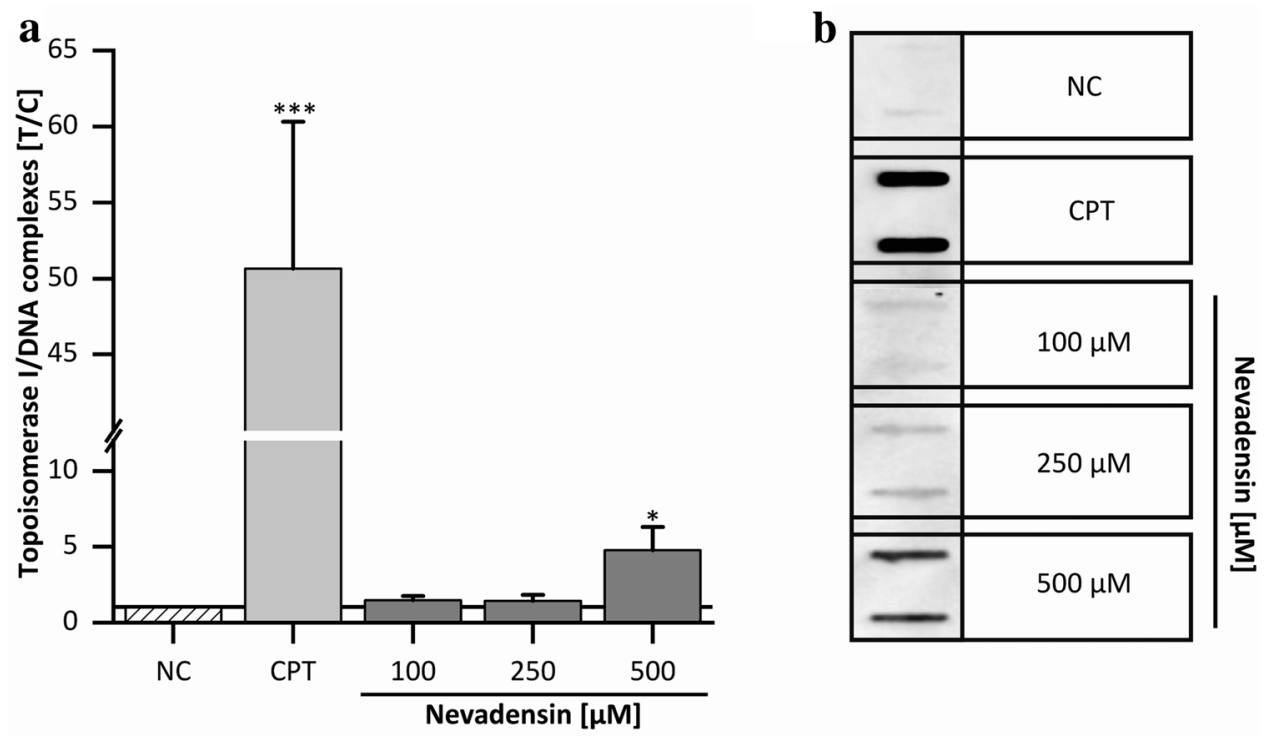

Fig. 5 TOPO I-poisoning effects in HT29 cells after $1 \mathrm{~h}$ of incubation with nevadensin. Effects were determined by visualisation of TOPO I bound to DNA using an HRP-linked antibody against TOPO I. DMSO (1\%) served as NC and CPT $(25 \mu \mathrm{M}$,) as PC. Nevadensin was tested at a concentration range from 100 to $500 \mu \mathrm{M}$ (a). The presented data are the mean \pm SD of at least three independent experi-

poison in human K562 leukaemia cells (López-Lázaro et al. 2010), indicating that the used test system and cell line could play a crucial role in identifying TOPO-poisons. Moreover, the used concentrations up to $500 \mu \mathrm{M}$ of nevadensin could also be not sufficient to stabilise TOPO II $\alpha /$ DNA complexes. In comparison, genistein showed effects at concentrations $\geq 100 \mu \mathrm{M}$ in the ICE-assay (Kalfalah et al. 2011). The collective data corroborates that nevadensin seems to be a less potent TOPO-poison compared to other flavonoids. Of note, the cellular metabolism as well as cellular uptake of the compound might vary depending on the cell type and thus, might impair effect strength of each flavonoid at a cellular level. In this respect, it is also proposed that the chemical structure of nevadensin plays the most crucial role for its TOPO-inhibiting effects. Nevadensin only carries two hydroxy groups at position C-5 and C-7 and thus differs from the aforementioned members of the flavonoid category. The extent of hydroxylation might contribute to their respective effectiveness to affect TOPO activity, especially considering, e.g. hexahydroxyflavone myricetin as a reference. This hypothesis can be further supported by the two structural parameters, which have been defined by Bensasson and co-workers (2011) as follows: (1) Their three-dimensional structure attributed to their affinity to DNA and (2) the possibility of transformation into quinones by different oxidation pathways including autoxidation, enzymatic oxidation as well as formation of reactive oxygen species. It has been shown that the presence of further substituents at position ments measured as duplicates. The amount of TOPO I/DNA intermediates was calculated as test over control $(T / C)$ in relation to DNA content. Significances levels were determined with one-way ANOVA (Tukey as post-hoc test) and refer to the lowest concentration of $100 \mu \mathrm{M}(* p<0.05, * * * p<0.001)$. A representative immune blot is shown in (b)

C-2 and C-3 increases the dihedral angle $\mathrm{O}-2-1^{\prime}-2^{\prime}$ between the chromone moiety and the phenyl ring these strongly influence DNA intercalation properties of flavonoids (Bensasson et al. 2011). Hydroxy groups at C-5 and C-4' as well as the aromatic planar $\mathrm{C}$-ring with the keto group at $\mathrm{C}-4$ are further characterised as crucial features for potent TOPO I poisons. In the case of TOPO II-poisoning, the substitution pattern of the B-ring is already proved to be essential for poisoning effects. Moreover, it is figured out that the presence of additional hydroxy moieties at position $\mathrm{C}-3^{\prime}$ and/or $\mathrm{C}-5^{\prime}$ at the C-ring enhance the poisoning effect by a redoxdependent mode of action (Bandele and Osheroff 2007). The hydroxy moiety at position $\mathrm{C}-5$, which is proposed to form a pseudo-ring with the aromatic, planar C-ring of flavanones bearing the ketone group at position $\mathrm{C}-4$, allows the interaction between compound and enzyme (Bandele et al. 2008; Kozerski et al. 2003; Austin et al. 1992). These findings imply that the absence of hydroxy groups at positions C- $3^{\prime}$ and $\mathrm{C}-5^{\prime}$ of flavonoids have a negative impact on TOPO II activity.

Besides aspects covering the cellular metabolism, the cellular uptake, and the structural diversity, $\mathrm{H}_{2} \mathrm{O}_{2}$ and ROS generation associated with flavonoids should be considered when investigating TOPO-poisoning effects. It is well known that the use of catalase reduces the formation of TOPO/DNA-complexes induced by (-)-epigallocatechin-3-gallate, gallic acid and myricetin in TRADIS assay indicating an impact of redox sensitive mechanisms 
(López-Lázaro et al. 2011). Most of the conducted studies with flavonoids were carried out without the application of catalase. Effects directly related to the compound could, therefore, not be distinguished from the secondary induction of $\mathrm{H}_{2} \mathrm{O}_{2}$ (Constantinou et al. 1995; López-Lázaro et al. 2010, 2011). This secondary effect might also be dependent on redox conditions applied in in vitro experiments and might not necessarily reflect the in vivo situation. In the presented experiments, the TOPO I poisoning effect of nevadensin is lower compared to the avaialble data for other flavonoids. Due to the use of catalse (see also 3.3.1), the direct impact of nevadensin plays the major role in the outcome under the conditions applied. However, the potential redox mechanism should be considered in follow-up studies to increase comparability between differnet flavonoids and to elucidate their lead mode of action in vitro/in vivo.

\section{Cellular response to TOPO I poisoning effects}

\section{DNA-damaging properties}

In literature, cleavable complex stabilisation and catalytic TOPO poisoning are associated with a reduced DNA integrity. Therefore, the DNA-damaging potential of nevadensin at concentrations of 50-500 $\mu \mathrm{M}$ was investigated in HT29 cells after two hours of incubation by using the alkaline

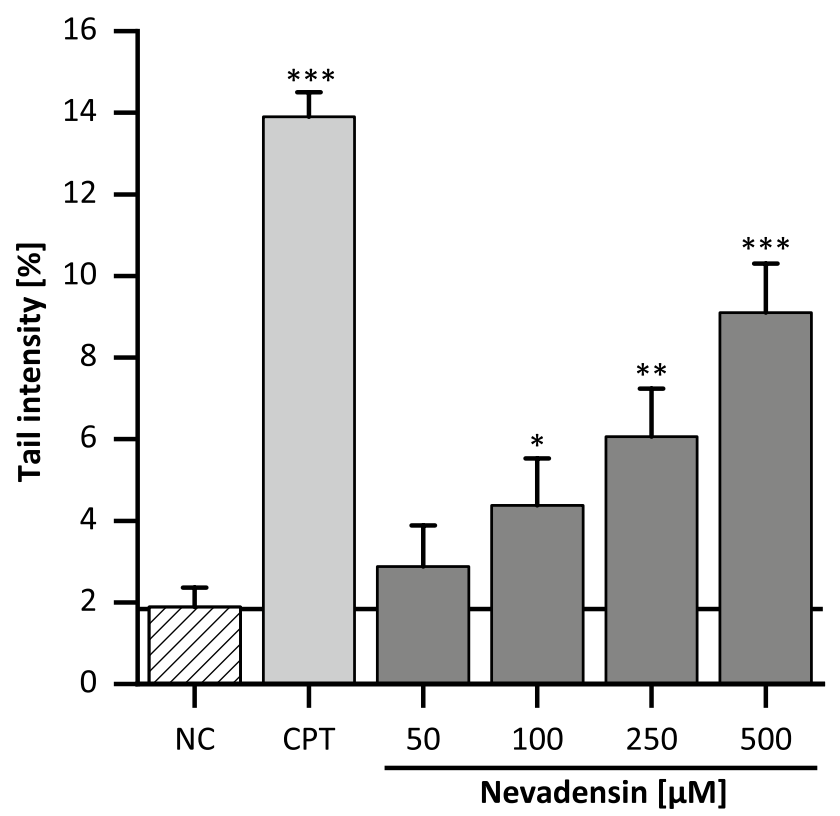

Fig. 6 DNA strand-breaking properties of nevadensin in HT29 cells after $2 \mathrm{~h}$ of treatment investigated by the alkaline comet assay. DMSO $(1 \%$; NC) served as NC and CPT $(100 \mu \mathrm{M})$ as PC. The presented data are the mean $\pm \mathrm{SD}$ of three independent experiments performed in technical duplicates. Significances refer to the NC (DMSO 1\%) and were determined with one-way ANOVA (Tukey as post-hoc test) $(* p<0.05, * * p<0.01, * * * p<0.001)$ comet assay. DMSO (1\%) and CPT $(100 \mu \mathrm{M})$ served as NC and $\mathrm{PC}$, respectively. A concentration-dependent increase of DNA damage was detected after $2 \mathrm{~h}$ (Fig. 6). Compared to the known TOPO I poison CPT (PC), nevadensin demonstrated a slightly lower DNA-damaging effect. In comparison with other TOPO-targeting flavonoids such as the isoflavone genistein, which is described as TOPOII $\alpha$ and TOPO II $\beta$ poison (Schroeter et al. 2019), nevadensin demonstrated higher DNA-damaging potential in all tested concentrations. Secondary oxidative DNA-damaging properties of flavonoids contribute to the overall DNA strand breaks (Schroeter et al. 2019). Based on the use of catalase (100 U/ $\mathrm{mL}$ ) in each cell-based experiment an artificial formation of $\mathrm{H}_{2} \mathrm{O}_{2}$ released from nevadensin into the cell culture media was excluded. The results from the FOX-assay reveal that the use of catalase completely prevents $\mathrm{H}_{2} \mathrm{O}_{2}$-formation (Supplementary Information Table 1). Based on these findings in accordance with missing structural conditions of nevadensin to act as redox-sensitive TOPO-poison, further investigations on oxidative DNA damage were not performed. It can be mentioned that the observed TOPOpoisoning effect of nevadensin is strongly associated with an enhanced DNA damage. At concentrations $\geq 100 \mu \mathrm{M}$, a significant increase of DNA strand breaks was found. In the ICE assay an enhanced TOPO/DNA complex formation was detected, but the effect was only significant at the highest concentration of $500 \mu \mathrm{M}$. The stabilisation of cleavage complexes by TOPO poisons is a reversible process. It is assumed that in lower concentrations, an adequate time period of complex stabilisation is not warranted for a densitometric evaluation. However, the expected level of TOPO/ DNA complexes might be likely sufficient to induce DNA damage. Nevertheless, it cannot be dismissed that the interaction with the minor groove and non-covalent association to DNA may also contribute to the formation of DNA strand breaks.

\section{Influence on cell viability and induction of cell cycle arrest}

The functions of TOPO enzymes are described to be essential for replication and mitosis; hence, TOPO-inhibitors decrease cell viability and/or induce cell cycle alterations. Therefore, the impact of nevadensin on cell viability was investigated by using the resazurin reduction assay. The cells were incubated in a concentration range of $1-500 \mu \mathrm{M}$ nevadensin for $24 \mathrm{~h}$ and $48 \mathrm{~h}$, respectively. DMSO (1\%) served as NC and CPT (200 $\mu \mathrm{M})$ as PC (Fig. 7). After an incubation time of $24 \mathrm{~h}$, a slight but significant reduction in cell viability about $20 \%$ was determined at nevadensin concentrations $\geq 250 \mu \mathrm{M}$. After $48 \mathrm{~h}$ the cell viability was significantly diminished but still higher than $50 \%$; thus an $\mathrm{IC}_{50}$ could not be calculated. 


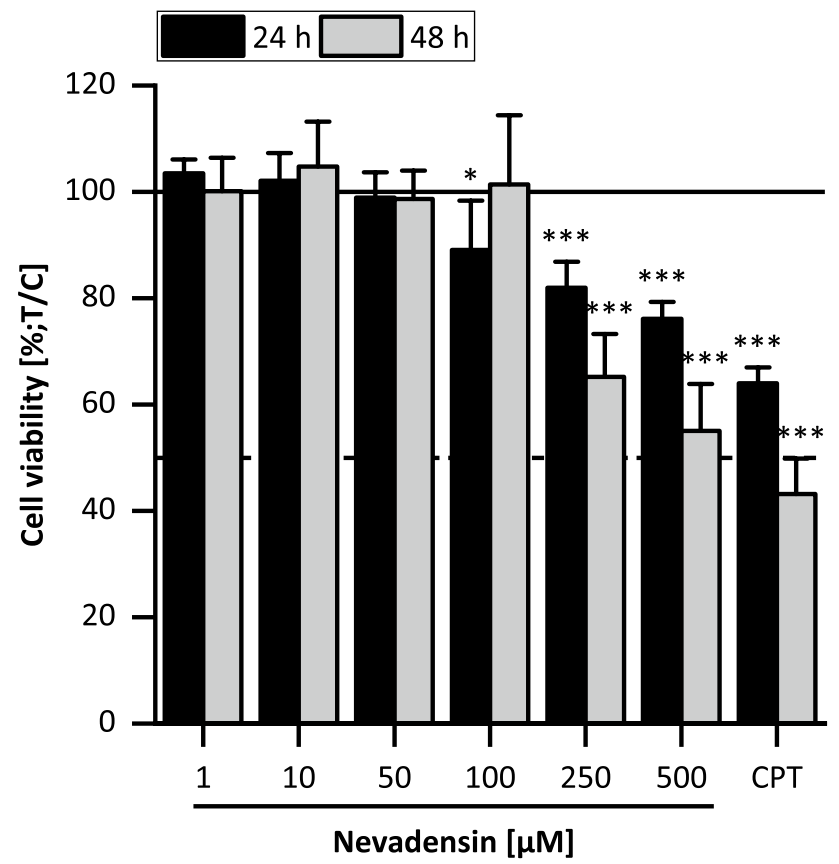

Fig. 7 Cytotoxic effects in HT29 cells after $24 \mathrm{~h}$ and $48 \mathrm{~h}$ incubation with nevadensin investigated by the resazurin assay. DMSO $(1 \%)$ served as NC and CPT $(250 \mu \mathrm{M})$ as PC. The presented data are the mean $\pm \mathrm{SD}$ of at least three independent experiments performed in a triplicate, calculated as test over control (DMSO $=100 \%)$. Significances were determined with one-way ANOVA (Tukey as posthoc test) and refer to the lowest concentration of $1 \mu \mathrm{M}\left({ }^{*} p<0.05\right.$, $* * * p<0.001)$ for each time point

Besides the impact of nevadensin on cell viability, investigations on cell cycle distribution were also observed. Furthermore, TOPO poisons are reported to induce a cell

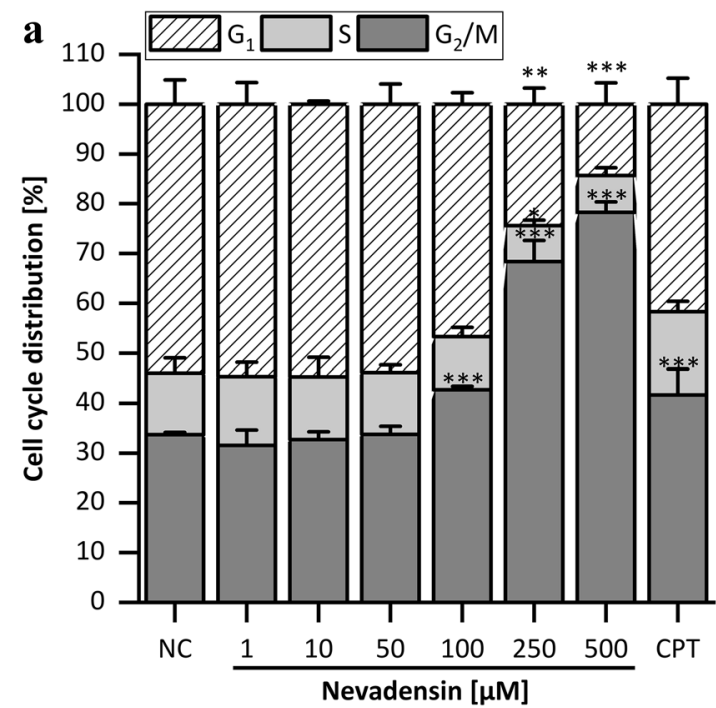

Fig. 8 Cell cycle distribution of synchronised HT29 cells after $24 \mathrm{~h}$ of incubation with nevadensin $(1-500 \mu \mathrm{M})(\mathbf{a})$. DMSO (1\%) was used as negative control (NC) and $100 \mu \mathrm{M} \mathrm{CPT}$ as positive control. The data presented are the mean $\pm \mathrm{SD}$ of three independent experiments. cycle arrest (Kaufmann 1998). Therefore, HT29 cells were incubated with a non-cytotoxic concentration of nocodazole $(100 \mathrm{nM})$ for $24 \mathrm{~h}$ for synchronisation in the $\mathrm{G}_{2} / \mathrm{M}$ phase (Supplementary Information Fig.S3) to ensure a coherent starting point for the subsequent compound treatment. Cells were incubated with nevadensin $(1-500 \mu \mathrm{M})$ for $24 \mathrm{~h}$. DMSO (1\%) served as NC and CPT (50 $\mu \mathrm{M})$ as PC (Fig. 8). An increase of cells in $\mathrm{G}_{2} / \mathrm{M}$ phase was found at nevadensin concentrations $\geq 100 \mu \mathrm{M}$. The effect of $500 \mu \mathrm{M}$ nevadensin on cell cycle distribution was considerably higher compared to CPT.

TOPO inhibition results inter alia in torsional stress during replication, which delays the transition of the cells from $S$ to $G_{2}$ phase. The subsequent cell cycle arrest is probably discussed as the result of the activation of the $\mathrm{G}_{2}$ control point. It is reported that the $G 2 / M$ checkpoint prevents the division of cells with damaged DNA and, therefore, provides a chance to DNA repair processes (Löbrich and Jeggo 2007; Kaufmann 1998). In relation to the obtained marginal cytotoxicity of nevadensin, it is assumed that the strong G2 cell cycle arrest might initiate further cellular response mechanisms such as DNA repair. However, the decrease in cell viability gives a hint that cytotoxic events such as apoptosis or necrosis also occur as cellular response to nevadensin treatment.

\section{Apoptotic or necrotic pathway}

For the investigations on cell death, the necrotic way of cell death was investigated, first. Therefore, the lactate dehydrogenase (LDH) leakage was used as marker

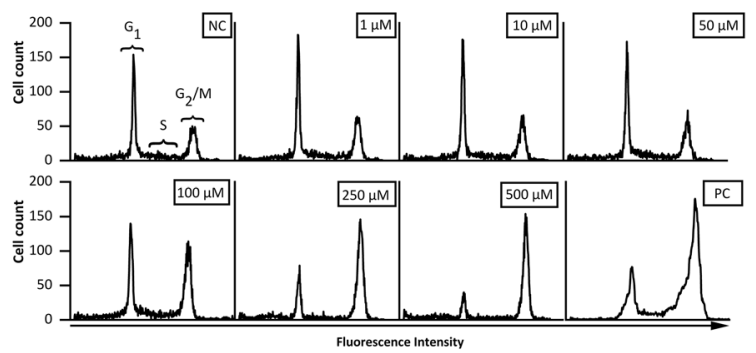

The significances were determined with one-way ANOVA (Tukey as post-hoc test) $(* * p<0.01, * * * p<0.001)$ and refer to the negative control. Representative histograms of cell cycle analysis (b) 

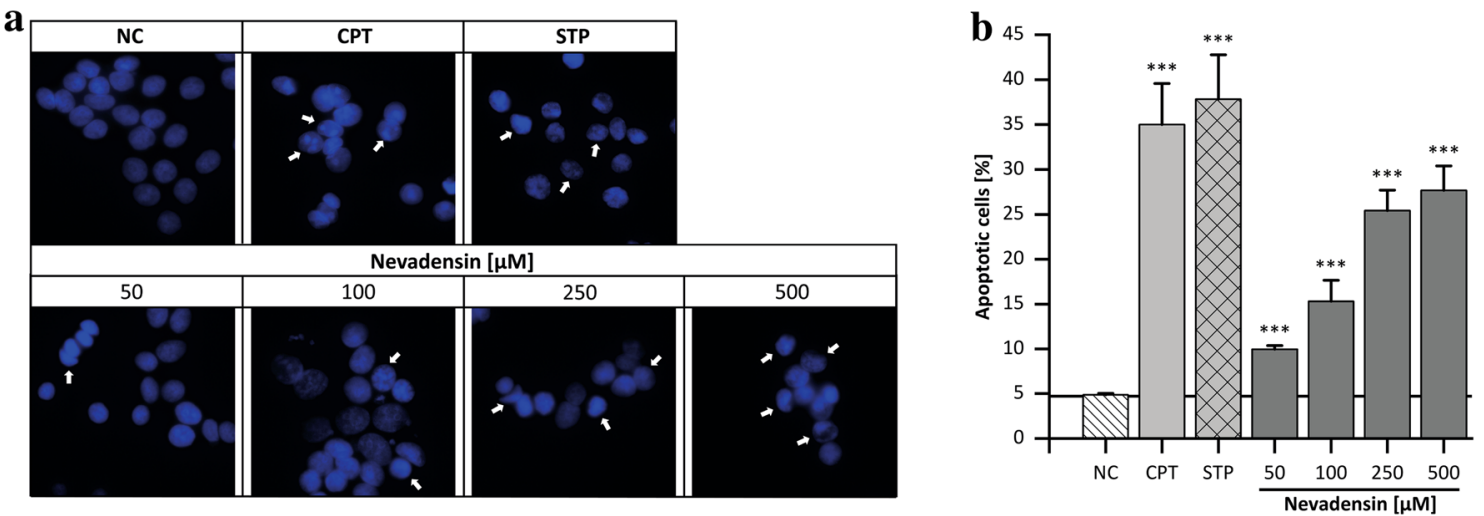

Fig. 9 Cellular apoptosis observed with Hoechst 33342 staining. HT29 cells were treated with nevadensin $(50-500 \mu \mathrm{M})$ for $24 \mathrm{~h}$. DMSO (1\%) was used as negative control (NC) and CPT $(0.5 \mu \mathrm{M})$ as well as staurosporine (STP; $1 \mu \mathrm{M})$ were used as positive controls, respectively. Representative pictures are presented in (a), examples for apoptotic cells were marked with arrows. For the determination of

for necrosis. HT29 cells were incubated for $24 \mathrm{~h}$ with nevadensin at concentrations of 50-500 $\mu \mathrm{M}$ because cytotoxic events occurred $>100 \mu \mathrm{M}$. LDH leakage was controlled with Triton X-100 as PC and DMSO (1\%) as NC. After treatment of HT29 cells with nevadensin an increased $\mathrm{LDH}$ release to the medium was not detected (Supplementary Information Fig. S4). Consequently, it is excluded that nevadensin induces cell death via necrosis at the selected time. Based on these findings, the induction apoptosis was determined via Hoechst 33342 staining, the number of apoptotic cells, 1,000 nuclei were counted, and the rate of apoptotic cells are given in per cent. The data presented are the mean \pm SD of three independent experiments (b). The significances were determined with one-way ANOVA (Tukey as post-hoc test) $(* * p<0.01, * * * p<0.001)$ and refer to $\mathrm{NC}$

first. In accordance with the cytotoxicity data an incubation time of $24 \mathrm{~h}$ was chosen. The assay was controlled by DMSO $(1 \%)$ as NC and CPT $(0.5 \mu \mathrm{M})$ as well as staurosporine (STP; $1 \mu \mathrm{M})$ as $\mathrm{PC}$, respectively. Nevadensin demonstrated a concentration-dependent increase of apoptotic cells in HT29 cells after 24 h (Fig. 9b). In addition to the deformation and morphological changes of the nuclei, nevadensin also induced alterations in the chromatin structure (Fig. 9a). In addition, caspase-3 activity was also investigated after $24 \mathrm{~h}$ to further confirm the induction

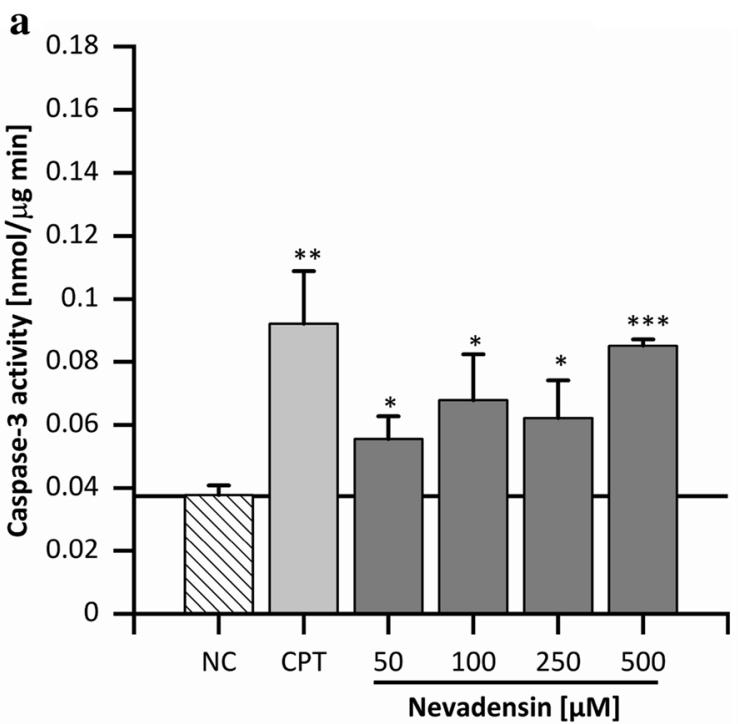

Fig. 10 Casapse-3 (a) and caspase-9 (b) activation in HT29-cells after $24 \mathrm{~h}$ of incubation with nevadensin $(50-500 \mu \mathrm{M})$. DMSO $(1 \%)$ served as NC, CPT ( $1 \mu \mathrm{M})$ was used as PC. Caspase- 3 and caspase-9 activation was analysed by using the specific substrates Ac-DEVD-

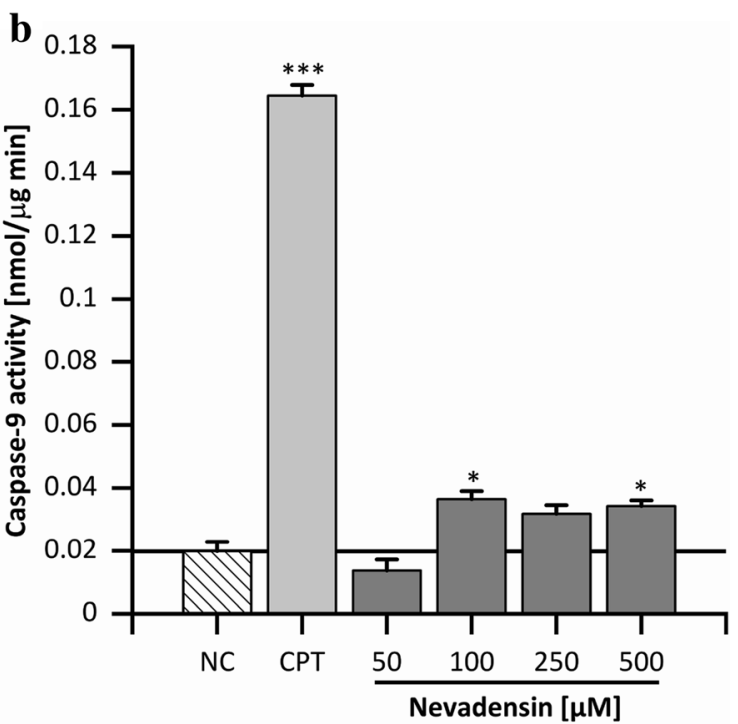

AFC and Ac-LEHD-AFC. The presented data are the mean $\pm \mathrm{SD}$ of three independent experiments. The significances were calculated with one-way ANOVA (Tukey as post-hoc test) $\left({ }^{*} p<0.05\right.$, $* * p<0.01, * * * p<0.001)$ and refer to the NC 
of apoptosis. The assay was controlled by CPT $(1 \mu \mathrm{M})$ as PC and DMSO (1\%) as NC. Nevadensin concentrationdependently increased caspase-3 activity and at $500 \mu \mathrm{M}$ (Fig. 10a), a twofold, highly significant effect was found. TOPO-associated DNA damage is reported to modulate different apoptotic signalling elements (Sordet et al. 2003). For the mechanistic characterisation of apoptosis and for distinguishing intrinsic and extrinsic apoptosis, the activity of the effector caspase- 8 and -9 was investigated. Caspase- 8 was used as cellular marker for the extrinsic apoptotic pathway, whereas caspase- 9 was implemented as an enzyme of extrinsic apoptosis. HT29 cells were treated using the parameters of the caspase 3 activity assay. Nevadensin significantly increased the activity of caspase-9 at concentrations $>50 \mu \mathrm{M}$ (Fig. 10b). In contrast, no influence of nevadensin on caspase- 8 activity was found (Supplementary Information Fig. S5). Compared to CPT an induction of both apoptotic pathways was excluded based on the negative caspase- 8 assay. The results are in line with further studies, characterising TOPO poisons as primary inductors of intrinsic apoptosis (Abotaleb et al. 2018). Furthermore, this apoptotic pathway is highly associated with reduced DNA integrity being in accordance with the results of the comet assay (Ashe and Berry, 2003). Nevertheless, a $\mathrm{G}_{2} / \mathrm{M}$ arrest was observed after $24 \mathrm{~h}$ of incubation, thus supporting the assumption that nevadensin-induced DNA damage is recognised by cells and subsequent activation of control mechanisms leads to apoptosis and triggers cell viability. However, further mechanisms such as DNA repair are emphasised due to the fact that cell viability was only reduced up to $50 \%$ after $48 \mathrm{~h}$ of incubation. Intracellular uptake and metabolism, and further genotoxic properties of nevadensin might also influence these cellular targets and should be focused on further investigations.

Finally, the question raises about the relevance of TOPO-poisoning effects of nevadensin as well as subsequent cellular response in vitro in accordance to intake and bioavailability of dietary flavonoids in vivo. There is a leak of data regarding to dietary intake of nevadensin itself, up to now. However, it is known that the daily intake of flavonoids in Europe is about $428 \pm 49 \mathrm{mg}$ per day (Vogiatzoglou et al. 2015). Data on the bioavailability of nevadensin in human are equally unknown, so far. Based on animal studies, it is demonstrated that nevadensin is distributed rapidly and eliminated rather quickly. However, it is reported that nevadensin absorption is very poor after intragastric gavage whereas the absorption of aqueous solution is described as rapid, but its bioavailability is also low (Brahmachari 2010). The maximal plasma concentration of nevadensin in the rat was determined at $169 \mathrm{nM}$ after single, oral administration of $50 \mathrm{mg} / \mathrm{kg}$ body weight (Liu et al. 2013). However, in the presented in vitro study micromolar concentrations were applied. It is concluded that systemic exposure after common dietary intake is unlikely to induce effects on TOPOs considering the available data basis. The systemic impact of dietary quantities of nevadensin on TOPO poisoning and its cellular effects is, therefore, rated as marginal. However, the local influence of the cellular uptake as well as the (cellular) metabolism in the gastrointestinal tract after dietary intake or in dosed form remains to be of scientific interest considering the very limited data situation in vivo.

Nevertheless, the presented in vitro study demonstrates mechanistical investigations on the impact of natural occurring food constituents on fundamental processes for the maintenance of DNA integrity and function is of utmost relevance for food safety.

\section{Conclusion}

In this study, the impact of nevadensin on human TOPOs were investigated in cell-free and cell-based in vitro test systems in a concentration range of 1-500 $\mu \mathrm{M}$. DNA-binding and intercalating properties were also examined because they are strongly associated with potent TOPO inhibitory properties. The investigations revealed that nevadensin has a high affinity to the minor groove of the DNA. In vitro models using isolated TOPOs characterised nevadensin as TOPO I and TOPO II $\alpha$ inhibitor. The mode of action was further clarified in the in vivo complex of enzyme assay in the human colon carcinoma cell line HT29. Nevadensin induced a stabilisation of the cleavage complex, indicating a TOPO I-poisoning effect, whereas an effect on cellular TOPO II $\alpha$ could not be verified in the tested concentration range. Furthermore, the study focused on the subsequent cellular response to TOPO I inhibition, whereby DNAdamaging effects, cytotoxicity, and cell cycle distribution were considered. It was found that nevadensin significantly induces DNA strand breaks resulting in a strong $\mathrm{G}_{2} / \mathrm{M}$ arrest. Additionally, investigations on cytotoxic effects demonstrated a significant decrease of cell viability after nevadensin treatment. Furthermore, the induction of apoptosis was proved by Hoechst 33,342 staining. The investigations on the mechanism of apoptosis induced by nevadensin indicated the intrinsic pathway, which is associated with caspase- 9 and caspase-3 activation. Differences in effect concentrations between cell-free and cellular models as well as current limitations of cytotoxicity (about $60 \%$ viable cells) suggest that metabolism and cellular uptake as well as DNA repair mechanisms are potential further key pathways of the mode of action of nevadensin.

This study clearly highlights the versatile cellular mechanisms of food-borne flavonoids. The results provide first 
insights into potential adverse effects as well as favourable properties of nevadensin. Both should be investigated more precisely in vivo with specific regard to human exposure.

Supplementary Information The online version contains supplementary material available at https://doi.org/10.1007/s00204-021-03162-5.

Acknowledgements This work was funded by a grant from the German Federal Ministry of Education and Research (01FP13061F). The authors thanks Dr. Matthias Behrens and Maria Hahn (both University of Münster) for technical assistance in flow cytometry.

Author contributions Conception and design of the experiments, data analysis and interpretations and manuscript preparation-LM and ME. Analysis and interpretation of further data for this publication-LM, LRFS, DB and JA. Critical reading and approval of the final version-LM, JA, TU and ME.

Funding Open Access funding enabled and organized by Projekt DEAL. This work was partly funded by the German Federal Ministry of Education and Research under the Reference No. 01FP13061F.

Availability of data and material All data generated or analysed during this study are included in this published article and its supplementary information files.

Code availability Not applicable.

\section{Declarations}

Conflict of interest The authors declare that they have no known competing financial interests or personal relationships that could have appeared to influence the work reported in this paper.

Ethic approval Not applicable.

Consent to participate Not applicable.

Consent for publication Not applicable.

Open Access This article is licensed under a Creative Commons Attribution 4.0 International License, which permits use, sharing, adaptation, distribution and reproduction in any medium or format, as long as you give appropriate credit to the original author(s) and the source, provide a link to the Creative Commons licence, and indicate if changes were made. The images or other third party material in this article are included in the article's Creative Commons licence, unless indicated otherwise in a credit line to the material. If material is not included in the article's Creative Commons licence and your intended use is not permitted by statutory regulation or exceeds the permitted use, you will need to obtain permission directly from the copyright holder. To view a copy of this licence, visit http://creativecommons.org/licenses/by/4.0/.

\section{References}

Abotaleb M, Samuel SM, Varghese E, Varghese S, Kubatka P, Liskova A, Büsselberg D (2018) Flavonoids in cancer and apoptosis. Cancers. https://doi.org/10.3390/cancers11010028
Alhusainy W, Paini A, Punt A, Louisse J, Spenkelink A, Vervoort J, Delatour T, Scholz G, Schilter B, Adams T, van Bladeren PJ, Rietjens IMCM (2010) Identification of nevadensin as an important herb-based constituent inhibiting estragole bioactivation and physiology-based biokinetic modeling of its possible in vivo effect. Toxicol Appl Pharmacol 245:179-190. https://doi.org/10. 1016/j.taap.2010.02.017

Ashe PC, Berry MD (2003) Apoptotic signaling cascades. Prog Neuropsychopharmacol Biolo Psychiatry 27:199-214. https://doi.org/ 10.1016/S0278-5846(03)00016-2

Austin CA, Patel S, Ono K, Nakane H, Fisher LM (1992) Site-specific DNA cleavage by mammalian DNA topoisomerase II induced by novel flavone and catechin derivatives. Biochem J 282:883-889. https://doi.org/10.1042/bj2820883

Bailly C, Dassonneville L, Colson P, Houssier C, Fukasawa K, Nishimura S, Yoshinari T (1999) Intercalation into DNA Is Not required for inhibition of topoisomerase I by indolocarbazole antitumor agents. Cancer Res 59:2853-2860

Bandele OJ, Osheroff N (2007) Bioflavonoids as poisons of human topoisomerase II alpha and II beta. Biochem Soc Symp 46:60976108. https://doi.org/10.1021/bi7000664

Bandele OJ, Clawson SJ, Osheroff N (2008) Dietary polyphenols as topoisomerase II poisons: $\mathrm{B}$ ring and $\mathrm{C}$ ring substituents determine the mechanism of enzyme-mediated DNA cleavage enhancement. Chem Res Toxicol 21:1253-1260. https://doi.org/10.1021/ tx 8000785

Baranello L, Kouzine F, Levens D (2013) DNA topoisomerases beyond the standard role. Transcription 4:232-237. https://doi.org/10. 4161/trns.26598

Bensasson RV, Zoete V, Jossang A, Bodo B, Arimondo PB, Land EJ (2011) Potency of inhibition of human DNA topoisomerase I by flavones assessed through physicochemical parameters. Free Radical Biol Med 51:1406-1410. https://doi.org/10.1016/j.freeradbio med.2011.06.021

Beretta GL, Perego P, Zunino F (2008) Targeting topoisomerase I: molecular mechanisms and cellular determinants of response to topoisomerase I inhibitors. Expert Opin Ther Targets 12:12431256. https://doi.org/10.1517/14728222.12.10.1243

Beretta GL, Zuco V, Perego P, Zaffaroni N (2012) Targeting DNA topoisomerase I with non-camptothecin poisons. Curr Med Chem 19:1238-1257. https://doi.org/10.2174/092986712799320529

Berim A, Gang DR (2016) Methoxylated flavones: occurrence, importance, biosynthesis. Phytochem Rev 15:363-390. https://doi.org/ 10.1007/s11101-015-9426-0

Brahmachari G (2010) Nevadensin: isolation, chemistry and bioactivity. Int J Green Pharm 4:213-219. https://doi.org/10.22377/ijgp. v4i4.150

Chai PC, Long LH, Halliwell B (2003a) Contribution of hydrogen peroxide to the cytotoxicity of green tea and red wines. Biochem Biophys Res Commun 304:650-654. https://doi.org/10.1016/ S0006-291X(03)00655-7

Chai PC, Long LH, Halliwell B (2003b) Contribution of hydrogen peroxide to the cytotoxicity of green tea and red wines. Biochem Biophys Res Commun. https://doi.org/10.1016/S0006-291X(03) 00655-7

Champoux JJ (2001) DNA topoisomerases: structure, function, and mechanism. Annu Rev Biochem 70:369-413. https://doi.org/10. 1146/annurev.biochem.70.1.369

Constantinou A, Mehta R, Runyan C, Rao K, Vaughan A, Moon R (1995) Flavonoids as DNA topoisomerase antagonists and poisons: structure-activity relationships. J Nat Prod 58:217-225. https://doi.org/10.1021/np50116a009

Deweese JE, Osheroff N (2010) The use of divalent metal ions by type II topoisomerases. Metallomics 2:450-459. https://doi.org/ $10.1039 / \mathrm{c} 003759$ a 
Erlund I, Silaste ML, Alfthan G, Rantala M, Kesäniemi YA, Aro A (2002) Plasma concentrations of the flavonoids hesperetin, naringenin and quercetin in human subjects following their habitual diets, and diets high or low in fruit and vegetables. Eur J Clin Nutr 56:891-898. https://doi.org/10.1038/sj.ejcn.1601409

Espín JC, García-Conesa MT, Tomás-Barberán FA (2007) Nutraceuticals: facts and fiction. Phytochemistry 68:2986-3008. https://doi. org/10.1016/j.phytochem.2007.09.014

Esselen M, Barth SW (2014) Food-Borne Topoisomerase Inhibitors. In: Fishbein JC, Heilman JM (eds) Advances in molecular toxicology, vol 8, 1st edn. Elsevier, pp 123-171

Esselen M, Fritz J, Hutter M, Marko D (2009) Delphinidin modulates the DNA-damaging properties of topoisomerase II poisons. Chem Res Toxicol 22:554-564. https://doi.org/10.1021/tx800293v

Esselen M, Boettler U, Teller N, Bachler S, Hutter M, Rufer CE, Skrbek S, Marko D (2011) Anthocyanin-rich blackberry extract suppresses the DNA-damaging properties of topoisomerase I and II poisons in colon carcinoma cells. J Agric Food Chem 59:69666973. https://doi.org/10.1021/jf200379c

Fritz J, Roth M, Holbach P, Esselen M, Marko D (2008) Impact of delphinidin on the maintenance of DNA integrity in human colon carcinoma cells. J Agric Food Chem 56:8891-8896. https://doi. org/10.1021/jf801522x

Fry AM, Chresta CM, Davies SM, Walker MC, Harris AL, Hartley JA, Masters JRW, Hickson ID (1991) Relationship between topoisomerase II level and chemosensitivity in human tumor cell lines. Cancer Res 51:6592-6595

Gedik CM, Wood SG, Collins AR (1998) Measuring oxidative damage to DNA; HPLC and the comet assay compared. Free Radical Res. https://doi.org/10.1080/10715769800300661

Grayer RJ, Veitch NC, Kite GC, Price AM, Kokubun T (2001) Distribution of 8-oxygenated leaf-surface flavones in the genus Ocimum. Phytochemistry 56:559-567. https://doi.org/10.1016/ S0031-9422(00)00439-8

Habermeyer M, Fritz J, Barthelmes HU, Christensen MO, Larsen MK, Boege F, Marko D (2005) Anthocyanidins modulate the activity of human DNA topoisomerases I and II and affect cellular DNA integrity. Chem Res Toxicol 18:1395-1404. https://doi.org/10. $1021 /$ tx050039n

Herz W, de Groote R (1977) Desacetyleupaserrin and nevadensin from Helianthus pumilus. Phytochemistry 16:1307-1308. https://doi. org/10.1016/S0031-9422(00)94387-5

Hevener K, Verstak TA, Lutat KE, Riggsbee DL, Mooney JW (2018) Recent developments in topoisomerase-targeted cancer chemotherapy. Acta Pharm Sin B 8(6):844-861. https://doi.org/10. 1016/j.apsb.2018.07.008

Jiang Z-Y, Hunt JV, Wolff SP (1992) Ferrous ion oxidation in the presence of xylenol orange for detection of lipid hydroperoxide in low density lipoprotein. Anal Biochem 202:384-389. https://doi.org/ 10.1016/0003-2697(92)90122-n

Kalfalah FM, Mielke C, Christensen MO, Baechler S, Marko D, Boege F (2011) Genotoxicity of dietary, environmental and therapeutic topoisomerase II poisons is uniformly correlated to prolongation of enzyme DNA residence. Mol Nutr Food Res 55(Suppl 1):S127S142. https://doi.org/10.1002/mnfr.201000509

Kaufmann SH (1998) Cell death induced by topoisomerase-targeted drugs: more questions than answers. BBA Gene Struct Expr 1400:195-211. https://doi.org/10.1016/S0167-4781(98)00136-5

Kern M, Fridrich D, Reichert J, Skrbek S, Nussher A, Hofem S, Vatter S, Pahlke G, Rüfer C, Marko D (2007) Limited stability in cell culture medium and hydrogen peroxide formation affect the growth inhibitory properties of delphinidin and its degradation product gallic acid. Mol Nutr Food Res 51:1163-1172. https:// doi.org/10.1002/mnfr.200700004

Kerrigan JE, Pilch DS (2001) A structural model for the ternary cleavable complex formed between human topoisomerase I, DNA, and camptothecin. Biochemistry 40:9792-9798. https://doi.org/ 10.1021/bi0109131

Kozerski L, Kamieński B, Kawecki R, Urbanczyk-Lipkowska Z, Bocian W, Bednarek E, Sitkowski J, Zakrzewska K, Nielsen KT, Hansen PE (2003) Solution and solid state 13C NMR and X-ray studies of genistein complexes with amines. Potential biological function of the C-7, C-5, and C4'-OH groups. Org Biomol Chem 1:3578-3585. https://doi.org/10.1039/b305991j

Krug I, Behrens M, Esselen M, Humpf H-U (2018) Transport of enniatin $\mathrm{B}$ and enniatin $\mathrm{B} 1$ across the blood-brain barrier and hints for neurotoxic effects in cerebral cells. PLoS ONE 13:e0197406. https://doi.org/10.1371/journal.pone.0197406

Ligasová A, Koberna K (2019) Quantification of fixed adherent cells using a strong enhancer of the fluorescence of DNA dyes. Sci Rep 9:8701. https://doi.org/10.1038/s41598-019-45217-9

Liu H, Yan C, Li C, Lin L (2013) LC-MS/MS determination of nevadensin in rat plasma and its application in pharmacokinetic studies. J Pharm Biomed Anal 74:56-61. https://doi.org/10.1016/j. jpba.2012.10.021

Löbrich M, Jeggo PA (2007) The impact of a negligent G2/M checkpoint on genomic instability and cancer induction. Nat Rev Cancer 7:861-869. https://doi.org/10.1038/nrc2248

Long LH, Clement MV, Halliwell B (2000) Artifacts in cell culture: rapid generation of hydrogen peroxide on addition of (-)-epigallocatechin, (-)-epigallocatechin gallate, (+)-catechin, and quercetin to commonly used cell culture media. Biochem Biophys Res Commun 273:50-53. https://doi.org/10.1006/bbrc.2000.2895

López-Lázaro M, Willmore E, Austin CA (2010) The dietary flavonoids myricetin and fisetin act as dual inhibitors of DNA topoisomerases I and II in cells. Mutat Res 696:41-47. https:// doi.org/10.1016/j.mrgentox.2009.12.010

López-Lázaro M, Calderón-Montaño JM, Burgos-Morón E, Austin CA (2011) Green tea constituents (-)-epigallocatechin3-gallate (EGCG) and gallic acid induce topoisomerase I- and topoisomerase II-DNA complexes in cells mediated by pyrogallol-induced hydrogen peroxide. Mutagenesis 26(4):489-498. https://doi.org/10.1093/mutage/ger006

Miron A, Aprotosoaie AC, Trifan A, Xiao J (2017) Flavonoids as modulators of metabolic enzymes and drug transporters. Ann NY Acad Sci 1398:152-167. https://doi.org/10.1111/nyas. 13384

Mittra B, Saha A, Chowdhury AR, Pal C, Mandal S, Mukhopadhyay S, Bandyopadhyay S, Majumder HK (2000) Luteolin, an abundant dietary component is a potent anti-leishmanial agent that acts by inducing topoisomerase II-mediated kinetoplast DNA cleavage leading to apoptosis. Mol Med 6:527-541

Morgan AR, Lee JS, Pulleyblank DE, Murray NL, Evans DH (1979) Review: ethidium fluorescence assays. Part 1 physicochemical studies. Nucleic Acids Res 7:547-569. https://doi.org/10.1093/ $\operatorname{nar} / 7.3 .547$

O'Brien J, Wilson I, Orton T, Pognan F (2000) Investigation of the Alamar Blue (resazurin) fluorescent dye for the assessment of mammalian cell cytotoxicity. Euro J Biochem 267:5421-5426. https://doi.org/10.1046/j.1432-1327.2000.01606

Ross JA, Kasum CM (2002) Dietary flavonoids: bioavailability, metabolic effects, and safety. Annu Rev Nutr 22:19-34. https://doi.org/ 10.1146/annurev.nutr.22.111401.144957

Salti GI, Grewal S, Mehta RR, Das Gupta TK, Boddie AW Jr, Constantinou AI (2000) Genistein induces apoptosis and topoisomerase II-mediated DNA breakage in colon cancer cells. Eur J Cancer 36:796-802. https://doi.org/10.1016/S0959-8049(00)00017-4

Schroeter A, Aichinger G, Stornig K, Marko D (2019) Impact of oxidative metabolism on the cytotoxic and genotoxic potential of genistein in human colon cancer cells. Mol Nutr Food Res 63:1800635. https://doi.org/10.1002/mnfr.201800635 
Silva G, Fachin AL, Beleboni RO, França SC, Marins M (2013) In vitro action of flavonoids in the canine malignant histiocytic cell line DH82. Molecules 18:15448-15463. https://doi.org/10.3390/molec ules 181215448

Snyder RD, Gillies PJ (2002) Evaluation of the clastogenic, DNA intercalative, and topoisomerase II-interactive properties of bioflavonoids in Chinese hamster V79 cells. Environ Mol Mutagen 40:266-276. https://doi.org/10.1002/em.10121

Sordet O, Khan QA, Kohn KW, Pommier Y (2003) Apoptosis induced by topoisomerase inhibitors. Curr Med Chem 3:271-290. https:// doi.org/10.2174/1568011033482378

Spector LG, Xie Y, Robison LL, Heerema NA, Hilden JM, Lange B, Felix CA, Davies SM, Slavin J, Potter JD, Blair CK, Reaman GH, Ross JA (2005) Maternal diet and infant leukemia: the DNA topoisomerase II inhibitor hypothesis: a report from the children's oncology group. Cancer Epidemiol Biomark Prev 14:651-655. https://doi.org/10.1158/1055-9965.EPI-04-0602

Strick R, Strissel PL, Borgers S, Smith SL, Rowley JD (2000) Dietary bioflavonoids induce cleavage in the MLL gene and may contribute to infant leukemia. PNAS 97:4790-4795. https://doi.org/10. 1073/pnas.070061297

van den Berg SJPL, Klaus V, Alhusainy W, Rietjens IMCM (2013) Matrix-derived combination effect and risk assessment for estragole from basil-containing plant food supplements (PFS). Food Chem Toxicol 62:32-40. https://doi.org/10.1016/j.fct.2013. 08.019

Vogiatzoglou A, Mulligan AA, Lentjes MAH, Luben RN, Spencer JPE, Schroeter H, Khaw K-T, Kuhnle GGC (2015) Flavonoid intake in European adults (18-64 years). PLoS ONE 10(5):e0128132. https://doi.org/10.1371/journal.pone.0128132

Wang Y-Q, Weng Z-M, Dou T-Y, Hou J, Wang D-D, Ding L-L, Zou L-W, Yu Y, Chen J, Tang H, Ge G-B (2018) Nevadensin is a naturally occurring selective inhibitor of human carboxylesterase 1. Int J Biol Macromol 120:1944-1954. https://doi.org/10.1016/j. ijbiomac.2018.09.178

Webb MR, Ebeler SE (2004) Comparative analysis of topoisomerase IB inhibition and DNA intercalation by flavonoids and similar compounds: structural determinates of activity. Biochem J 384:527541. https://doi.org/10.1042/BJ20040474

Wisnuwardani RW, de Henauw S, Androutsos O, Forsner M, Gottrand F, Huybrechts I, Knaze V, Kersting M, Le Donne C, Marcos A, Molnár D, Rothwell JA, Scalbert A, Sjöström M, Widhalm K, Moreno LA, Michels N (2019) Estimated dietary intake of polyphenols in European adolescents: the HELENA study. Eur J Nutr 58:2345-2363. https://doi.org/10.1007/s00394-018-1787-x

Woynarowski JM, McHugh M, Sigmund RD, Beerman TA (1989) Modulation of topoisomerase II catalytic activity by DNA minor groove binding agents distamycin, Hoechst 33258, and 4',6-diamidine-2-phenylindole. Mol Pharmacol 35:177-182

Yamashita N, Kawanishi S (2000) Distinct mechanisms of DNA damage in apoptosis induced by quercetin and luteolin. Free Radical Res 33:623-633. https://doi.org/10.1080/1071576000 0301141

Publisher's Note Springer Nature remains neutral with regard to jurisdictional claims in published maps and institutional affiliations. 